\title{
Sağlık Sektöründe Yönetsel Etik Kaygılar
}

\author{
Mucize Sarıhan ${ }^{1 *}$, Onur Yarar $^{2}$ \\ 1* İstanbul Okan Üniversitesi, SHMYO, İstanbul, Türkiye (ORCID: 0000-0001-8013-7370) mucize.sarihan@okan.edu.tr \\ ${ }^{2}$ İstanbul Okan Üniversitesi, SHMYO, İstanbul, Türkiye (ORCID: 0000-0001-9543-6891) onur.yarar@okan.edu.tr
}

(İlk Geliş Tarihi 18 Nisan 2021 ve Kabul Tarihi 9 Eylül 2021)

(DOI: 10.31590/ejosat.826022)

\begin{abstract}
ATIF/REFERENCE: Sarıhan, M. \& Yarar, O. (2021). Sağlık Sektöründe Yönetsel Etik Kaygılar. Avrupa Bilim ve Teknoloji Dergisi,
\end{abstract} (27), 267-282.

\section{$\ddot{\mathbf{O z}}$}

Etik kavramı, insan hayatının birçok farklı noktasında önemi hissedilen bir konuya işaret etmektedir. Özellikle de hayatın bazı alanlarında etik, kritik bir değere sahiptir. Bunlardan biri olarak sağlık sektöründe, etik kuralların ve uygulamaların gerçekleştirilmesi hem sektörün güvenilirliği hem de insan sağlığına verilen önemin gösterilmesi adına önem taşımaktadır. Özellikle de çalışanların sektör içerisindeki, hastalarla ve sağlık hizmeti almak isteyen tüm bireyler ile doğrudan iletişim halinde oldukları düşünülecek olursa, onların konumları, etik kavramının karara bağlanması açısından son derece önemli olmaktadır. Bu çalışmada, sağlık sektörü ve çalışanları (hemşireler ve teknikerler) açısından etik kavramının ne anlam ifade ettiği? Alanda karşılaştıkları etik sorunlar, ikilemler ve özellikle yönetim temelli etik sorunlar konusundaki görüşleri ve kaygıları araştırılmıştır. Bu amaçla çalışanlarla yüz yüze görüşmeler yapılarak, bu görüşmeler doğrultusunda elde edilen veriler nitel araştırma yöntemi uygulanarak değerlendirilmiştir. Sağlık çalışanları için 9 maddelik açık uçlu sorular hazırlanmıştır. Farklı hastanelerde ve kliniklerde çalışan 10 kişiden oluşan hemşire ve tekniker ile yapılan görüşmeler kayıt altına alınmıştır. Görüşmeler Covit 19 salgını nedeni ile hastane dışında gerçekleşmiştir. Elde edilen veriler MAXQDA 2020 veri analiz programı kullanılarak değerlendirilmiştir. Analiz sonucunda meslek etiği çerçevesinde 7 ana tema ve onların alt kodları belirlenmiştir. Elde edilen ana temalar; Sağlık Etiği, etik ikilemler, motivasyon, yönetimsel etik sorunlar, diğer etik sorunlar, maddi çıkar elde etme, yazılı kurallar olarak belirlenmiştir. Yönetim temelli etik sorunlar temasına ait doğrudan 9 alt kod ve dolaylı olarak 3 alt kod tespit edilmiş ve bu kodlar değerlendirilmiştir. Etik ikilemler, çalışanlar üzerinde performans düşüklüğüne neden olurken; malzeme eksikliği ve malzemelerin kalitesiz olması, çalışanlara karşı duyarsız davranma gibi yönetim bazlı sorunların da çalışanların motivasyonlarını düşürdüğ̈̈ belirlenmiştir. Klinik bazlı etik sorunlar temasında ise çalışma sahasında tecrübeli elemanların değer görmediği ve bu durumun motivasyonu düşürdüğü yönündedir. Yazılı kurallar temasında dikkat çekici nokta genel anlamda uyulması yönünde olumlu sonuçlar verdiği ve çalışanları güvende hissettirdiği yönündedir. Yazılı kurallar teması ile ilgili en önemli tespit ise çalışanların çalışma sırasında doğru alışkanlıklar geliştirmelerini sağlamaları açısından etkili olduğunun ifade edilmesidir. Yönetsel etik teması çalışanlar tarafından en çok vurgulanan tema olmasıdır. Yönetime bağlı etik sorunlar; iş yoğunluğu, personel eksikliği, malzeme eksikliği, malzeme kalite eksikliği, takdir görmeme, fiziki alan eksikliği, döner sermaye eşitsizliği, sık eleman değişimi gibi alt kodlar ile tespit edilmiştir. Sağlık sektörü verdiği hizmet bakımından hassas bir sektördür. Yapılacak hataların toleransı yoktur. Bu anlamada sağlık çalışnaları oldukça yoğun çalışmaktadır ve yapılan çalışmada eleman yetrsizliğide bu soruna eşlik ettğinde işelerin daha da zorlaştığı ifade edilmektedir. Gerek kurumsal yönetim bazında gerekse klinik yönetimi bazında çalışanlara karşı motive edici davranışlar onları hem moral hem de performans olarak etkileyecektir. Kliniklerde eksikliklerin giderilmesi ve kalitenin benimsenmesi çalışanların işlerini kolaylatırmanın yanında verilen hizmetin kalitesini de etkileyecektir. Bunun yanı sıra yönetimin, yoğun iş yükü altında olan çalışanlara değerli hissetmelerini sağlayacak takdir edici geri bildirimler sunmaları, yeterli eleman sağlanması ve eksikliklerin giderilmesi yönündeki çalışmalar iş performansı ve motivasyonlarını yükselterek, daha kaliteli bir hizmet, çalışanlar arasında refah ortamı yaratacaktır. Bu konu ile ilgili hizmet içi eğitimlerin yepılmasıda önemlidir.

$\mathrm{Bu}$ doğrultuda çalışma alanları farklı olan hemşire ve teknikerler kendi alanlarında yaşadıkları etik sorunlarla ile igili farklı tema ve kodlar oluşturmamızı sağlamışlardır. Ayrıca çalışmada yönetsel etik sorunlar vurgulanmıştır ve bu bağlamda iki yönetsel etik sorun tespit edilmiştir.

Anahtar Kelimeler: Etik, Sağlık Etiği, Yönetsel Etik.

\section{Management Ethics in the Health Sector with Its Theoretıcal Bases}

\begin{abstract}
The concept of ethics points to a subject whose importance is felt at many different points in human life. Ethics has a critical value, especially in some areas of life. As one of these, the implementation of ethical rules and practices in the health sector is important in terms of both the reliability of the sector and the importance given to human health. Especially considering that employees in the sector are in direct contact with patients and all individuals who want to receive health services, their positions are extremely important in terms of deciding the concept of ethics. What does the concept of ethics mean for the health sector and its employees (nurses and technicians) in this study? Their views and concerns about the ethical problems they encounter in the field and especially about the ethical problems arising from management were investigated.
\end{abstract}


For this purpose, face-to-face interviews were conducted with the employees and the data obtained in line with these interviews were evaluated by applying the qualitative research method. 9-item open-ended questions were prepared for healthcare professionals. Interviews with 10 nurses and technicians working in different hospitals and clinics were recorded. The interviews took place outside the hospital due to the COVID-19 outbreak. The obtained data were evaluated using the MAXQDA 2020 data analysis program. As a result of the analysis, 7 main themes and their sub-codes were determined within the framework of professional ethics. The main themes obtained; Health Ethics has been determined as ethical dilemmas, motivation, managerial ethical problems, other ethical problems, obtaining financial benefits, and written rules. 9 direct subcodes and 3 indirect subcodes belonging to the theme of management-based ethical problems were identified and these codes were evaluated. While ethical dilemmas cause poor performance on employees; It has been determined that management-based problems such as lack of materials, poor quality of materials, insensitive behavior towards employees also reduce the motivation of employees.

In the theme of clinical-based ethical problems, it is stated that experienced personnel in the field of study are not valued and this situation reduces motivation. The remarkable point in the theme of written rules is that it gives positive results in general terms and makes employees feel safe. The most important determination regarding the theme of written rules is that it is effective in enabling employees to develop correct habits during work. The theme of managerial ethics is the one most emphasized by the employees. Ethical issues related to management; work intensity, lack of personnel, lack of material, lack of material quality, lack of appreciation, lack of physical space, inequality of revolving funds, frequent personnel changes. The health sector is a sensitive sector in terms of the services it provides. There is no tolerance for mistakes to be made. In this sense, health professionals work very hard and it is stated in the study that the work becomes more difficult when the lack of personnel accompanies this problem. Motivating behaviors towards employees, both on the basis of corporate management and clinical management, will affect them both in terms of morale and performance. Eliminating the deficiencies in the clinics and adopting the quality will not only facilitate the work of the employees, but also affect the quality of the service provided. In addition, the management's efforts to provide appreciative feedback to employees who are under heavy workloads that will make them feel valuable, to provide sufficient staff and to eliminate deficiencies will increase their work performance and motivation, and create a better quality service and an environment of well-being among employees. It is also important to have in-service training on this subject.

In this direction, nurses and technicians with different fields of study enabled us to create different themes and codes regarding the ethical problems they experienced in their fields. In addition, managerial ethical problems were emphasized in the study and two managerial ethical problems were identified in this context.

Keywords: Ethics, Health Ethics, Managerial Ethics.

\section{Giriş}

Etik unsuru, insan hayatının birçok noktasında kendisini göstermekte ve nitelikli iş, iletişim, yaşam süreçlerinin oluşturulması adına bireylere bir zemin yaratmaktadır. Çoğunlukla insan ilişkilerinin yoğun olduğu noktalarda ön plana çıkan etik unsuru, bazı konularda çok daha büyük önem arz etmektedir. Böylelikle insanların çıkarlarını doğrudan ilgilendiren noktalarda, sürecin gidişatına doğrudan etki etmektedir. Bu açıdan bakıldığında etik, insan hayatının belki de en önemli belirleyicisi olmakta ve ahlaki değerler bütünü ile bir arada değerlendirildiği süre zarfında insan hayatının daha doğru ve daha fazla, toplum genelince kabullenilmiş değerlere uygun olmasına yaramaktadir.

Sağlık alanı, etik kavramının en fazla gözetilmiş olduğu alanlardan biridir. Buna göre sağlık sektörünün geneli ve özellikle de sektör çalışanları, etik unsurların son derece fazla gözetilmesi gerekliliği üzerine inşa edilen bir sistemin içerisindedirler. İnsan sağlığının kritik bir öneme sahip olduğu bu sektör için önceliğin insana verilmesi ve insan için gereken her şeyin yapılması, sektörün ve sektör çalışanlarının insani duygularının ön plana çıkarıldığının gösterilmesi adına önemlidir. Yıllar içerisinde giderek daha fazla ticari bir kimlik kazanan sağlık sektörü, böyle bir kimliğe sahip olsa da aslında temel olarak taşıdığı kimlik, insan hayatını göz önünde bulundurarak insanın iyiliğine hizmet etmesidir. Bu durumda sağlık sektörü ve sektörün çalışanları için etik kavramı da daha fazla tartışılan bir noktaya ulaşmıştır.

Sağlık sektöründe sunulan hizmetler kamusal nitelik taşıyan hizmetler olması bakımından önemlidir. Ayrıca, sağlık hizmetlerinin sunulma biçimi formal bir nitelik taşımaktadır ve bu hizmetler çalışanlara önemli bir sorumluluk yüklemektedir (Utlu, N. 2013). Hastanelerde çalışan hemşireler ve teknikerler en önemli hizmet sunucular arasında yer almaktadır. Özellikle hemşireler 24 saat esasına göre çalışmaları nedeniyle sundukları hizmet şekli oldukça yoğundur. Diğger yandan hasta yoğunluğu yaşanan diğer sağlık grubu ise teknikerlerdir. Sağlık çalışanlarının yoğunluklarının diğer bir nedeni de etik değerlere bağlı kalmalarından dolayıdır. Ancak hastalar, hasta yakınları ve yönetsel anlamda ortaya çıkan bazı etik sorunlar çalışanların performans ve motivasyonlarını etkilemektedir. Özellikle sağlık çalışanlarının sektör içerisindeki, hastalarla ve sağlık hizmeti almak isteyen tüm bireyler ile doğrudan iletişim halinde oldukları düşünülecek olursa, onların konumları, etik kavramının karara bağlanması açısından son derece önemli olmaktadır. Daha önce yapılan çalışmalarda etik iklim ve çalışanlar üzerindeki yıldırma politikası incelenmiş ve anket çalışması yapılarak çalışanlar üzerindeki baskılar değerlendirilmiştir Utlu N. (2016). yaptığg araştırmada devlet hastanesinde hemşireler ile görüşmeler yapmış ve yapılan görüşmelerde mesleki etik, sağlık etiği ve etik sorunlar üzerinde durulmuş, bu konudaki görüşleri değerlendirilmiştir. Han H. (2018) ise hemşirelerin etik sorunları üzerine yaptığı araştırmada mobing vurgusu yapmıştır. Aydan S. (2017) Etik konusu ile ilgili yaptığ 1 tez çalışmasında etik iklim ve örgütsel güvenin ihbarcılık niyeti üzerine etkileri değerlendirmiştir. Amerikan Hekim Yöneticileri Birliğinin (American Collage OF Physician Executives; ACPE) 2005 yılında yaptığı araştırmada etik dışı uygulamaların yaklaşık \%54 olduğuna dikkat çekmesi etik davranışın sağlık örgütleri açısından önemini ortaya koymuştur. Yapılan çalışmalarda çalışma ortamındaki etik sorunların mobing'e neden olduğu bildirilirken, etik ihlallerin ise malpraktısa neden olduğu belirtilmiştir. Araştırmamızda farklı hastane ve bölümlerde görev yapan hemşireler ve teknikerler araştırma kapsamına alınmış ve yüz yüzyüze görüşmeler yapılarak, çalışma ortamında yaşadıkları etik sorunlar, ikilemler ve yönetim temelli etik sorunların ve kaygıların neler olduğu tespit edilmesi amaçlanmıştır. 


\section{Etik Kavramı}

\subsection{Teorik Olarak Etik Kavramı}

Etik, kelime olarak, kişi ya da mesleğin davranışlarını düzenleyen ahlaki ilkeler grubu ya da değerler topluluğu olarak tanımlanmaktadır (Kutlay \& Yılmazlar, 2001).

Etik sözcüğü köken olarak eski Yunanca bir sözcük olan ethos sözcüğünden gelir. Bu sözcüğü kökeninde ethica sözcüğü vardır. Buradaki etika sözcüğü, ethos sözcüğünün çoğulu olan "ethe'ye ilişkin konular" anlamına gelmektedir. Ethos 'un çoğulu olan ethe, en eski anlamıyla söylenirse, "canlı bir varlığın 'mekân'1, 'hep gittiği, sığındığı yer' anlamına” gelmektedir (Kuçuradi, 1997). Ethe İlk anlamıyla "bir canlının barındı̆̆ı, sı ğındığı yer, ortam" anlamına gelmektedir. Tekili olarak ethos sözcüğü de karakter, huy demektir (Köseoğlu Z, 2011).

Etik, bireylerin toplumsal olarak gerçekleştirdiği ve başka bireyleri etkileyici sonuçları olan eylemleri/yapıp etmeleri / davranışları ve bunları şekillendiren düşünce süreçleri ile bağlantılıdır. Bu bağlamda etik 3 şekilde somut olarak karşımıza çıkar. Felsefenin alanı anlamında etik, davranışlar bağlamında bireylerin ideal davranış şekillerini formüle eder. Bunun yanısıra nelerin iyi olduğu ve iyinin ne olduğu konusunu ele almaktadır.

Toplum yaşamında etiğin karşılığı, insanların birbirleriyle ilişkilerinde neleri yapmaları ve nelerden kaçınmaları gerektiğiyle ilgili bir kurallar kümesi; kısaca genel ahlaktır (Gülay Yıldırım, Selim Kadıoğlu. (2007).

\subsection{Bazı Teorisyenler ve Etik Yaklaşımları}

\subsubsection{Adam Smith}

Yoğun olarak iktisadi alana dair çalışmalar yapmış olan Adam Smith, iktisat teorisi içerisinde etik ile ilgili farklı yaklaşımlara sahip olmakla birlikte, zaman içerisinde bu etik anlayışını, toplumun genel ahlak yapısıyla bütünleştirmiş ve buna istinaden de yeni bir etik mekanizması oluşturmaya çalışmıştır.

Smith, toplumun etik anlayışının benimsenmesi ve benimsetilmesi konusunda, genelleyen bir tarza sahiptir. "Ahlaki Duygular Kuramı ve Hukuk Felsefesi Üzerine Dersler" adlı eserinde, bireysel anlamdaki ahlaki duyguların önemine dikkat çekmiş, ancak bunların önemli olmasının, sadece bireylerin kendi başlarına bir ahlaki değerler silsilesi oluşturmalarına sebebiyet vereceğini düşünmüştür. Bu nedenle, Antik Yunan'dan gelen bir şekilde savunduğu "polis" şeklindeki siyasi yönetim anlayışını da ön plana çıkararak, tüm toplumun, önceden belirlenmiş, bir ve açık olan etik değerler silsilesine itibar etmesi gerektiğini dile getirmiştir (Gürkan, 2013).

Öte yandan Adam Smith için etik, basit bir akıl yürütme ile de kesinliğe kavuşturulabilecek olan bir konudur. Her ne kadar tüm insanlar için ortak bir etik sisteminin gerçekleştirilmesi konusunda genellemeci olsa da Smith, bu etik düzeyinin zihinsel anlamda, herkesin ortak bir şekilde düşünmesi vesilesi ile de benimsenebileceğini dile getirmiştir. Smith'e göre toplumun ahlaki anlamda ihtiyacı olan unsurlar bellidir ve bu unsurların hemen hepsi herkes tarafindan ortak şekilde nitelikli bir şekilde algılanabilecektir (Levent, 2013). Bu noktada Smith'in görüşüne göre kendisinin etik anlamdaki genelleyen bakış açısının bir baskı unsuru olarak algılanmaması gerektiğine dair bir yaklaşımının olduğu fark edilmektedir. O'nun açısından eğer ki toplumun ahlaki anlamda doğruyu ve yanlışı ayırt etme kapasitesi zaten belli ise ortak ve genel geçer bir etik düzeni herkesin çıkarına olacaktır.

$\mathrm{Bu}$ sayede sadece etik değil, aslında adaletli bir toplum oluşturulabileceğini dile getiren Smith, etik kavramının sadece bir aracı unsur olduğunu düşünmektedir. Çünkü adaletin hâkim olduğu ve herkes tarafından benimsenmiş bir adaletin kesinliği toplumun kabul göstereceği bir durumdur. Bu nedenle de adaletin tesisi önemlidir, ancak adalet, herkesin kabul ettiği etik bir ahlaki yapının olmadığı ortamda; herkesin kendince haklı olduğu bir ortamda kendisine yaşam alanı bulamayacaktır (Livvarçin \& Kurt, 2012).

\subsubsection{Karl Marks ve Etik Yaklaşımı}

Büyük ölçüde görüşlerini işçi sınıfının toplumsal olarak çıkarlarının gözetilerek yüceltilmesi üzerine konuşlandıran Marks, bu şekilde görüşlerinin temeline, ahlaki değer bütünlüğü ve kurallar açısından işçi sınıfının çıkarlarını yerleştirmektedir. Temel olarak Marks, herhangi bir şekilde, spesifik bir etik anlayışına itibar etmemektedir. Etik kavramına bakış açısı olumlu olsa da kendisi etik kavramına uyum sağlamaya çalışmamakta, kendi ahlaki değerlerinin etik üzerinde etkili olmasına odaklanmaktadır. Bir başka deyişle Marks, kendi belirlediği etik değerlerin kabul görmesi gerektiği konusunda baskıcı bir tutum sergilemektedir (Eğri, 2008).

Öte yandan Marks için önem arz eden konu, etik bir kurallar silsilesi oluşturulacaksa, bu konuda mutlak olarak uluslar ve toplumlar üstü, güçlü bir yapının kurulması gerekmektedir. Çünkü etik, düşünüldüğü kadar sıradan bir yap1 üzerine inşa edilebilecek bir durumda değildir. Marks için etik bir kurallar silsilesi olacak ve proletarya üzerinden bu sistem işleyecekse mutlak olarak proletaryanın değerlerinin üzerinde, kabul edilebilir ve güçlü bir yapısının olması gerekmektedir (Yıldırım, 2012).

Her ne kadar Marks çalışmalarında etik ve ahlak olgularından doğrudan doğruya bahsetmese de O'nun temel hedefi, herkesi ortak bir doğru etrafinda toplamak ve bunun korunması adına birleştirmektir. Tıpkı siyasi görüşlerinde olduğu gibi sosyolojik bakış açısında da birleştirici bir yapıdan bahsetmek mümkündür. $\mathrm{Bu}$ birleştiricilik nitelikli ve değerli bir düzenin diğer insanların inandığı, ancak yozlaşmamış ahlaki değerler ile de açıklanabilecektir, ancak sınıfsal düzenin değişimi açısından hiçbir kimseyi diğerinden ayırmamak gayesinde olmalıdır (Öztürk, 2015).

\subsection{Etik Konusunda Yapılan Çalışmalar}

Kördeve (2017), “Özel Sektör Sağlık Çalışanlarında Etik Tutum ile Whistleblowıng Arasındaki İlişki” başlıklı araştırmasında, örnek olaylar ekseninde, söz konusu olaylara sağlık çalışanlarının bakış açılarını incelemeye çalışmıştır. Çalışmada katılımcıların \%94,4'ü örnek olayda geçen hastane kaynaklı bebek ölümlerinde hatayı amirine rapor edeceğini, \%72,6's1 hatayı kendi ismini vererek rapor edeceğini, \%90,3’ü hatadan üst yönetimi haberdar edeceğini, \%31,4'ü hatayı sahte isimle rapor edeceğini ifade etmiştir. Çalışmaya göre özel sektör sağlık çalışanları arasında etik ve yasa dışı olayların ihbarı benimsenmiş bir durumdur. Kördeve'nin bu araştırmasında ön plana çıkan konu, etik dişı olayların sağlık çalışanları tarafından fark edildikleri süre zarfında mutlak olarak, çözümleri için gereken mercilere iletiliyor olmalarıdır. 
Kırılmaz ve Kırılmaz (2014), tıp literatürüne dair yapmış oldukları değerlendirmede, sağlık konusundaki etiğin hayati önemine ve sağlık personelinin tutum ve davranışlarının ne denli belirleyici olduğuna değinmiştir. Buna göre sağlık çalışanlarının almış oldukları mesleki eğitimin içerisinde sağlık etiğinin de bulunması son derece büyük bir öneme sahiptir. Sadece tıbbi müdahalelerin değil, operasyon ve teşhis, tanı gibi süreçlerin dâhilindeki sağlık etiği ile uyumlu davranışlar hastaların hayatını kurtarabileceği gibi başarısız uygulamaların hastalara vereceği zararların da önüne geçmektedir (Kırılmaz \& Kırılmaz, 2014).

Doğan ve Karataş (2011) "Örgütsel Etiğin Çalışan Memnuniyetine Etkisi Üzerine Bir Araştırma” başlıklı araştırmalarında, örgütsel etik, liderlik ve çalışan memnuniyeti kavram ve olgularını bir arada ele almışlardır. Buna göre örgütsel etiğin çalışan memnuniyetindeki önemini ortaya koymak amacıyla, sağlık çalışanları arasında yapılan bu araştırma sonucunda elde edilen bulgular, örgütsel etiğin çalışan memnuniyetini olumlu yönde etkilediğini göstermektedir. $\mathrm{Bu}$ sonuca göre, sağlık örgütlerinin başarıya ulaşmasında çalışan memnuniyeti çok önemli bir etken olması vesilesi ile yöneticilerin çalışanlarıyla ilişkilerinde etik ilkeler çerçevesinde davranması gerektiği kanaatine varılmıştır. Çalışanlar etik ilkeler çerçevesinde yapılandırılan örgütsel etiği, kendilerine etik davranışlar göstererek model olan yöneticileri sayesinde algılayabileceklerdir (Doğan \& Karataş, 2011). Bir başka deyişle örgütsel etik açısından etkisi bulunan unsurların çalışanlara doğru bir şekilde aktarılması sonucunda onlardan yüksek ölçekli verim alınması kolaylaşmaktadır. Bu durum da onların etik konusundaki tutumlarını güçlendirmektedir.

Dündar (2010), bir önceki Doğan ve Karataş'ın çalışmalarına paralel olarak gerçekleştirdiği araştırmasında benzer ve daha detaylı sonuçlara erişilmiştir. Buna göre araştırmada, hastane yöneticilerinin sergiledikleri baskıcı ve zarar veren tutumların çalışanların huzurlu ve sağlık etik kurallarına bağlı olarak çalışmalarını engellediği tespit edilmiştir. Öte yandan araştırmanın çarpıcı sonucu, bu tür baskı uygulayan yöneticilerin, hastane ortamında önceliği herhangi bir şekilde başarılı ve sağlık odaklı, etik bir yönetim anlayışına vermedikleri; aksine, finansal anlamda kazanımlar ve karlılık odaklı olarak değerlendirdikleri görülmüştür (Dündar, 2010).

Şen vd. (2013), "Kamu Hastanelerinde Görev Yapan Başhekim ve Başhemşirelerin Duygusal Zekâ Düzeyleri ile Etik Muhakeme Yetenekleri ve Etkileyen Faktörler" başlıklı araştırmalarında, başhekim ve başhemşirelerin duygusal zekâ düzeyleri ile etik muhakeme yeteneklerinin iyi düzeyde olduğu süre zarfında, yöneticilerin cinsiyet ve eğitim durumunun duygusal zekâ düzeyini, yaşın ise etik muhakeme yeteneğini etkilediğini, başhemşire grubunda duygusal zekâ düzeyi arttıkça etik muhakeme yeteneğinin de arttığını belirlemişlerdir. Yüksek duygusal zekâya ve etik muhakeme yeteneğine sahip yöneticilerin kurumsal performansı ve çalışanlar arasındaki ilişkiyi olumlu yönde etkileyeceğini fark etmişlerdir (Şen ve ark., 2013). Bu araştırmada da yöneticiler ile çalışanlar arasındaki ilişsilere odaklanılmakta, bu şekilde de söz konusu ilişkilerin zincirleme etkisi içerisinde iş etiğine ne denli bir etkinin bulunduğu anlaşılmaya çalışılmıştır ki etik değerlendirme becerisinin bu ilişkilerin yönüne bağlı olduğu anlaşılmaktadır.

Gül (2006), "Etik Dışı Davranışlar ve Ussallaştırılması: Devlet Hastanelerinde Bir Uygulama" başlıklı çalışmasında, etik dışı davranışların nedenleri ve sonuçlarını sağlık çalışanları üzerinden değerlendirmiştir. Buna göre Gül'ün çarpıcı olarak eriştiği sonuç ile etik dışı davranışların çalışanlarda verimsizliğe, düşük performansa, devamsızlığa ve moral bozukluğuna neden olduğu bulgusuna ulaşı1mıştır. Ayrıca etik dışı davranışların örgüt yönetimlerince düzenlenmesine yönelik çabaların, çalışanların verimlilik düzeylerinin yükselmesi, bağlılık ve rekabet güçlerinin artmasına yol açtığı sonucuna varılmıştır (Gül, 2006).

Şahin ve Dündar (2011), "Sağlık Sektöründe Etik İklim ve Yıldırma (Mobbing) Davranışları Arasındaki İlişkinin İncelenmesi" başlıklı araştırmalarında, örgüt yönetimi-çalışan ilişkilerini etik açıdan ele almaya çalışmışlardır. Araştırmalarında farklı değerlendirmelerde bulunan araştırmacılar, özellikle çalışanların üzerindeki iş yükünün önemi üzerinden değerlendirmede bulunmuşlardır. Buna göre uzun saatler boyunca çalışmak durumunda kalan sağlık personeli, etik odaklı unsurları daha fazla göz ardı etmektedirler (Şahin \& Dündar, 2011).

Şahinoğlu ve Bebek (2018), “Araştırma görevlilerinin Bilimsel Araştırma Etiğine İlişkin Algıları” başlıklı araştırmalarında, çalışmamıza benzer şekilde nitel yöntem kullanmışlardır. Hazırlanan 8 maddelik yarı yapılandırılmış açık uçlu sorular ile basit rastgele örneklem yöntemi kullanarak katılımcılar ile yüz yüze derinlemesine görüşmeler yapmışlardır. Çalışmaya 8 araştırma görevlisi katılmış ve Etik kavramı ile ilintili 5 ana tema üzerine durmuşlardır. Bu ana temalar "ahlak, çalmamak/sahtekarlık yapmamak, kurallara uymak, dürüstlük, toplum ve yaşam olarak belirlenmiştir. Bizim çalışmamızda da ahlaklı olmak, sağlık çalışanları görevlerini yaparken etik davranmak olarak ifade edilmiştir. Kurallara uymak teması ile ilintili olarak ise "kurallara uymak doğru davranışlar geliştirir çalışma disiplini sağlar v.b şekilde olumlu değerlendirmeler yapılmıştır. Nitel araştırma desenlerinde yarı yapılandırılmış sorularla derinlemesine yüzyüze görüşmeler yapılması ve hatta katılımcının sorular dışında kendi görüşlerine de yer vermesi çalışmayı önem kazandırmaktadır. Katılımcı görüşleri sadece sorulan sorular sınırlı olmadığından konu ile ilgili sorunların belirlenmesi nitel çalışmalar bakımından önemlidir. $\mathrm{Bu}$ görüşmeler kayda alınarak, yazıya dökülerek, temalar ve ilgili kodlar değerlendirilmektedir.

\subsection{Sağlık Sektöründe Etik}

Sağlık sektöründeki insan hayatına dair hassasiyet göz önünde bulundurulduğu süre zarfında, sektörün içerisinde görev alan tüm bireylerin davranışları kadar kurallar bütününün de mutlak olarak hassasiyet dâhilinde şekillendirmesi gerekmektedir. $\mathrm{Bu}$ açıdan, sıklıkla dile getirilen etik kavramı, sürecin içerisinde önemli bir noktayı işaret etmekte ve insan hayatını korumak adına ciddi ölçekli bir etik birikimi gerektirmektedir.

Sağlık sektöründeki etik sistem, temel olarak sağlık çalışanlarının hastalara karşı olan tutum ve davranışlarıyla, sağlık konusunda atmaları gereken adımların hepsini kapsamaktadır. Bunun içerisinde hastaların durumlarının teşhisinden şartlarının iyileştirilmesine; onlarla birebir iletişim kurulmasından sağlık süreçleri için yönlendirilmelerine kadar uzanan silsiledeki birçok farklı davranış yer almaktadır. Sağlık sektörü açısından etik, hastalara doğru şekilde yaklaşmayı içermektedir (MEGEP, 2015).

Sağlık Sektöründe etik açısından önem arz eden noktaların başında, sektörün içerisinde yer alan görevlilerin, özellikle de doktorların hastalarla olan ilişkilerindeki uygulamaları ve hastalara bakış açıları gelmektedir. Sektörün genelinde, hastaların varlığı ve içerisinde bulundukları rahatsızlıklar son derece önemli olmakla birlikte hastaların tercih haklarının da dikkatle dinlenerek 
onlara yol gösterilmesi son derece önemlidir. Bu nedenle sağlık sektöründe etik, hastaların karşısındaki duruşla belli olmaktadır (Türk Kardiyoloji Derneği, 2009).

Öte yandan sağlık sektörü, dünya genelinde, üzerindeki politikaların en fazla değişim göstermiş olduğu alanlardan biridir. $\mathrm{Bu}$ nedenledir ki etik sistemleri ve algılamaları da bu süreçte belirli yönde bir değişim yaşayabilecektir. Genel olarak etik konuların, alışılagelmiş olunan şekilde devam etmesi son derece doğal karşılansa da değişen dünya şartları dahilinde, etik unsurların da zamanla değişim içerisine girmesi söz konusudur. $\mathrm{Bu}$ nedenle sektörün içerisinde yer alan tüm unsurlar, mutlak olarak değişen şartları göz önünde bulundurmak ve etik standartları da buna göre şekillendirmek durumundadırlar (Roberts, 2010).

\subsection{Sağlık Sektörü Çalışanlarında Etik}

Etik tutum ve davranışlar sergilenmesi adına en kritik alanlardan biri olarak dikkati çeken sağlık sektörü ve özellikle çalışanları temelinde bu sürecin önemli bir bölümünü sürdürmektedir. Bir başka deyişle sağlık sektörü çalışanları, sektörün etik ilkelerini gözetmek ve bu vesile ile de hastalara destek olmak durumundadırlar. Aynı zamanda sağlık çalışanlarının etik algıları, sağlık kuruluşlarının da etik algılarının bir yansımasını oluşturmaktadır.

Sağlık sektörü çalışanlarının etik anlayışları, çoğunlukla tıp etiği temelinde değerlendirilmektedir. Tıp etiği, tıbbi anlamda gerçekleştirilen tüm müdahalelerin, yönlendirmelerin ve değerlendirmelerin, sağlık açısından insanların bekasını düşünmek üzere oluşturulan değerler bütününü ifade etmektedir. Geniş bir kavramsal çerçevesi olan tıp etiği, sadece sağlık operasyonlarını değil, sağlık sektörü içerisindeki tüm yönetim süreçlerini de kapsamaktadır (Uğur, 2011).

Tıp etiği, sağlık sektörünün içerisinde, herhangi bir noktada çalışan bir birey için görevini tam olarak yerine getirmenin çok ötesinde bir kavramı ifade etmektedir. Buna göre tıp etiği, süreç olarak insan hayatını doğrudan ilgilendirecek nitelikteki tüm tıbbi olayları, nitelikli bir şekilde değerlendirmek ve insanların sağlıklarının sürdürülebilirliğine hizmet etmek adına birçok kuralın ve normun göz önünde bulundurulmasıly ortaya çıkmaktadır (World Medical Association 2015, World Medical Association 2008).

Sağlık alanı, önceliğin maddi çıkarlara verilerek değerlendirmeye tabi tutulacak bir alan olarak değerlendirilmemelidir. $\mathrm{Bu}$ noktada ön planda olması gereken, insan sağlığıyla birlikte yardım etme konusunda bireylerin her birini eşit olarak değerlendirme becerisidir. Tibbi etik bu şekilde ortaya çıkmakta ve ayrımcılığın olmadığı bir ortamda daha da güçlenmektedir. Ayrıca sağlık sektörü içerisindeki herkesin, özellikle de sağlık çalışanlarının mesleğe olan inançları giderek artmaktadır. Bu nedenle de sağlık sektörü çalışanları açısından etik algısı yerleşik bir hal almaktadır (Tepecik ve Yazıcı, 2012). Sağlık çalışanlarının yoğun bir şekilde insanlarla etkileşim içerisinde olduğu düşünüldüğünde bu etik anlayışına olan katılım ve uyumları kritik bir değere sahiptir.

Tıp etiğinde ön plana çıkarılan ve sağlık sektöründe çalışan tüm bireylere uymaları konusunda yönlendirmede bulunulan ilkeleri aşağıdaki gibi sıralamak mümkündür (MEGEP, 2011):
- Otonomi ilkesi: Otonomi ilkesi, hastaların haklarına saygı göstermek ve tıbbi bakım ile ilgili kararlara onların katılımını sağlamaktır.

- Yararlılık İlkesi: Tıp etiğinin, en eski ilkesi yararlılık ilkesidir. Bu ilke, sayesinde sağlık çalışanı hastanın yaşamına destek verir, onu tedavi ederek ağrı ve acısını dindirir. Her durumda hastaya yararlı olur. Tıp etiğinde yararlılık ilkesine koşut giden ilke kötü davranmama ilkesidir.

- Aydınlatılmış Onam İlkesi: Hastaya tıbbi bilgilerin doğru ve yeterli biçimde açıklanmasını isteyen ilkedir. Bu ilkenin gerçek bir aydınlatılmış onam olması için hastaya verilmesi gereken bilgilerin açıkça verilmiş olması, bilginin anlaşılır olması, hastanın gönüllü ve bunların sonunda hastanın onam vermiş olmas1 gerekmektedir.

- Adalet İlkesi: Bu ilke, tıbbi kaynakların ihtiyaca göre dürüstçe ve hakça paylaştırılmasını gerektirmektedir. Bu ahlaki ilke ile tedavi ve bakımda, kullanılan araç gereç ve teknik donanım kaynakları, hastanın bireysel gereksinimleri belirlenerek eşitlik ilkesine uygun olarak dağılımı sağlanır.

- Dürüstlük ve Doğruluk İlkesi: Bu iki ilke, hasta ve ailesine gerçeği söyleme, dürüst olma, yalan söylememe zorunluluğunu getirir. İnsanlar kendileri hakkındaki gerçeği öğrenmeye ve yalan söylenilmemesi hakkına sahiptir. Böylece sağlık personeli, hasta ve ailesi arasındaki ilişkilerin, dürüst, güvenilir bir ortamda kurulması sağlanır.

- Sır Saklama İlkesi: Sağlık personeli, sağlık bakım kurumunda hastalar hakkında öğrendiği tüm bilgileri gizli tutmak durumundadir.

Yukarıda sıralanan unsurlara bakıldığında, sağlık sektöründeki çalışanların ve sektörün genel şartlarının, aslında tamamıla hastaların ve ihtiyaç sahiplerinin sağlıklarını ve kimliksel değerlerini korumaya odaklandığını göstermektedir. Genel olarak sağlık sektöründe etik denen unsur hem maddi hem de manevi anlamda söz konusu olmaktadır. Hastaların sağlık durumlarının iyileştirilmesine dair çabalarla birlikte aynı zamanda genel durumlarına dair bilgilerin gizliliğinin sağlanması, sağlık sektörünün maddi ve manevi anlamdaki etik unsurların teşkil etmektedir.

Etik konusu sağlık sektöründe genellikle, hastalara dair etik unsurlar temelinde ele alınsa da aslında sürecin içerisinde sağlık sistemlerinin yönetimi konusu da bulunmaktadır. Bu noktada yönetsel etik unsurlar devreye girmektedir. Yönetsel etik açısından bakıldığında hizmetlerin ve hizmetler için gerekli malzeme ve materyallerin sağlanması konusu da sürecin oldukça önemli bir bölümüdür. Yönetim tarafından tıbbi malzemelerin satın alımı, kalitesi, kullanım özellikleri ve hastaların ihtiyaçlarına göre bu unsurların değerlendirilmesi sürecin etik tarafını oluşturmaktadır. Diğer yandan çalışanların, hastaların ihtiyacı olmayan sağlı ürünlerini onlara pazarlamaya çalışması, gereksiz yere kullanılan ilaçlar, kullanılmayan tıbbi ürünlerin hastalara fatura edilmesi vb. tüm yasa dışı sayılabilecek unsurlar, sağlık çalışanları açısından etik olmayan unsurları teşkil etmektedir (Avc1 \& Teyyare, 2012).

Sağlık çalışanları açısından süreçte belki de etik dışı unsurların temelini oluşturan en önemli konu hastaların ihtiyaçları dışındaki unsurları satın almaya yönlendirilmeleridir. Gerek hizmet gerekse tıbbi malzeme konusunda hastaların istekleri, tedavi süreçlerinin gereksinimleri dışındaki yönlendirilme şekilleri, sağlık sektöründe etik açıdan kritik bir durumu teşkil 
etmektedir. Özellikle de yüksek getirisi olacağı düşünülerek hastalara gereğinin dışında tıbbi unsur verilmesi, tıbbi cihazlarla olan etkileşimlerinin yine ticari kaygılarla üst düzeye çıkarılması, sağlık sektörünün etik olmayan boyutunu ifade edeceği gibi hastaların sağlı̆̆ını da ciddi ölçekli olarak tehdit edecektir (Durmaz \& Erdem, 2017).

\section{Materyal ve Metot}

Çalışmada yüz yüze derinlemesine görüşme tekniği uygulanmış ve görüşmeler kayıt altına alımıştır. Sonrasında görüşmeler word'e akatarılarak değerlendirme yapılmıştır.

Araştırmanın tarihi ve evreni; Şubat- Nisan 2021 tarihleri arasında İstanbul İli içerisinde kamu ve özel hastanelerde görev yapan sağlık çalışanlarını kapsamaktadır. Katılımcıları belirlemek için amaçlı örnekleme yöntemlerinden ölçüt örnekleme kullanılmıştır. Kriter temelli örneklem olarak da bilinen ölçüt örneklem araştırılan olguya yönelik deneyimlere sahip kişileri temsil eden bireylerden seçilir (Creswell J.W 2013). Bu bilgi doğrultusunda ve araştırma kapsamında katılımcılar aşağıdaki ölçütler belirlenerek tespit edilmiştir: Sağlık alanında çalışmış veya çalışıyor olmak, farklı hastane ve farklı kliniklerde çalışıyor ya da çalışmış olmak, hemşire ve sağlık teknikeri olarak çalışıyor olmak olarak belirlendi.

$\mathrm{Bu}$ doğrultuda araştırmanın örneklemini farklı kliniklerde (onkoloji, kemoterapi, cerrahi, paltyatif bakım) çalışan hemşireler ve teknikerler (radyoterapi, nükleer tıp, anestezi) oluşturmaktadır. Charmaz, veri toplama sürecinin temaları doygunluğa ulaştığında sonlandırılması gerektiğini vurgulamaktadır. Yeni verilerin toplanmasıyla ilgili yeni bakış açıları veya yeni özellikler ortaya çıkmadığında görüşmelerin durdurulmasını önermiştir (Creswell J.W 2013). Bu görüş 1şığında, araştırma kapsamındaki katılımcıların verilere verdikleri cevaplar aynı şekilde tekrarlamaya başladığı gözlenmiştir ve veri toplama süreci ve 10 . Katılımcı sonrası sonlandırılmıştır.

Yapılan araştırma sonucunca elde edilen bulgular, görüşmeye katılan sağlık çalışanları; hemşire ve teknikerler ile sınırlı bulunmaktadır. $\mathrm{Bu}$ nedenle farklı hastanelerdeki farklı sağlık çalışanları ile yapılacak araştırmalar için sonuçlar o araştırmanın analizine göre analiz edilmesi gerekmektedir. Araştırmanın kapsamında ele alınmış olan değişkenlerin zaman zarfında değişime uğrayabileceği değerlendirilmelidir. $\mathrm{Bu}$ çalışmanın verileri Şubat-Nisan 2021 tarihleri arasında elde edilmiştir.

Bu çalışmada sağlık çalışanlarının Yönetsel etik (kurum ve klinik), mesleki etik, sağlık etiği, etik sorunlar, etik ikilemler, yazılı kuralların etkisi konusunda görüşlerinin değerlendirilmesine yönelik nitel araştırma yapılmıştır. Araştırmacı tarafından alanında uzman kişilerin görüşleri de alınarak, 9 maddelik yarı yapılandırılmış açık uçlu sorular hazırlanmıştır. Hazırlanan bu sorular çerçevesinde sağlık çalışanları ile derinlemesine görüşmeler yapılmıştır. Bulguların içeriği bağlamında; kamu ve özel hastanede görev yapan sağlık çalışanları ile Covit 19 salgını nedeniyle, hastane dışında rahat bir ortamda görüşleri alınarak veriler elde edilmiştir. $\mathrm{Bu}$ veriler sonucunda görüşleri incelenmiştir. Bu görüşler betimleyici analiz yapılarak kodlar ve temalar çıkarılarak içerik analizi yöntemiyle değerlendirme yapılmıştır. $\mathrm{Bu}$ verileri değerlendirmek için MAXQDA 2020 veri analiz programı kullanılmıştır.

Nitel araştırma yönteminin tercih edilme sebebi, araştırmanın içinde bulunan örneklem grubunun sahip olduğu deneyim ve davranışlarından doğan anlamların doğal ortamda, gerçekçi ve bütüncül bir biçimde sistematik olarak incelenebilmesinde kullanılan bir teknik olmasıdır (Creswell, 2013). Nitel araştırmanın bir diğer özelliği ise keşfedici olmasıdır. Bu özelliği taşıyan araştırmaların kullanışlı ve yararlı yönlerinden biri, az çalışılmış konuları aydınlatıp açığa çıkarmasıdır (Neuman, 2007).

\section{Araştırmanın Bulguları}

\subsection{Demografik Dağılım}

Araştırmaya katılan sağlık çalışanlarının demografik özellikleri aşağıdaki tabloda verilmiştir. Çalışanların cinsiyete özel değişkenlerine bakıldığında \%80'i kadın, 20\%' si erkek olarak belirlendi. Sağlık çalışanlarının çalışma süresini belirten değişkenler; \%50'si 0-5 y1l, \%30'u 6-10 y1l, \%20'si ise 11-20 yıl arasında olduğu görülmektedir. Çalıştıkları kuruma bakıldığında ise $\% 50$ çalışanın devlet kurumunda, \%50 çalışanın ise özel kurumlarda hizmet verdikleri görülmektedir Çalışmaya katılan çalışanların \%60’ı hemşire, \%40'ının ise tekniker olduğu tespit edilmiştir (Tablo 1).

Tablo 1. Demografik Dağılım

\begin{tabular}{|c|c|c|}
\hline CINSIYET & Sıklık & \% \\
\hline Kadın & 8 & 80,00 \\
\hline Erkek & 2 & 20,00 \\
\hline Toplam & 10 & 100,00 \\
\hline ÇALIŞMA SÜRESI & & $\mathbf{\%}$ \\
\hline $0-5$ Y11 & 5 & 50,00 \\
\hline 6-10 Y1l & 3 & 30,00 \\
\hline $11-20$ Yil & 3 & 20,00 \\
\hline TOPLAM & 10 & 100,00 \\
\hline HASTANE TİII & & $\mathbf{\%}$ \\
\hline Özel & 5 & 50,00 \\
\hline Kamu & 5 & 50,00 \\
\hline Toplam & 10 & 100,00 \\
\hline MESLEK GRUBU & & $\mathbf{\%}$ \\
\hline Hemşire & 6 & 60,00 \\
\hline Tekniker & 4 & 40,00 \\
\hline TOPLAM & 10 & 100,00 \\
\hline
\end{tabular}




\subsection{Kavram Haritası Temalar, Kodlar ve Alt Kodlar}

Farklı hastane ve klinikte görev yapan sağlık çalışanları “çalıştığınız klinikte çalışma yoğunluğunuz nasıl? Sorusuna tamamı yoğun bir tempoda çalıştıklarını ifade etmişlerdir. Etik kavramı çerçevesinde sorulan sorulara karşılık elde edilen verilere göre kavram haritası, temalar ve kodlar oluşturulmuştur.

Çalışmaya katılan sağlık çalışanları meslek etiği çerçevesinde 7 ana tema üzerinde durmuşlardır. Elde edilen veriler sonucunda ilk tema sağlık etiği temasıdır. Sağlık etiğinin 4 alt kodu tespit edilmiştir. Bu kodlar; tedavi sırasında dikkatli olma, hastalar arasında adaletli olma, vicdani duygularla hareket etme ve malpraktıs şeklindedir. Diğer ana tema "yönetsel etik sorunlar" temasıdır. Doğrudan ve dolaylı olarak 9 alt kod belirtilmiştir. Bu anlamda en fazla alt koda sahip olan bu tema en fazla vurgulanan ve etkin olan bir özellik taşımaktadır. Üçüncü olarak "yazılı kurallar" temasının doğrudan ve dolaylı olarak 6 alt kodu tespit edilmiştir.

4. tema "diğer etik sorunlar" teması altında 3 maddelik alt kod tespit edilmiştir. Etik ikilemler, motivasyon, maddi çıkar

temalarının alt kodları ise 2 şer madde olarak belirlenmiştir. Kavram haritası kodlar ve alt kodlar şekil 1'de yer verilmiştir.

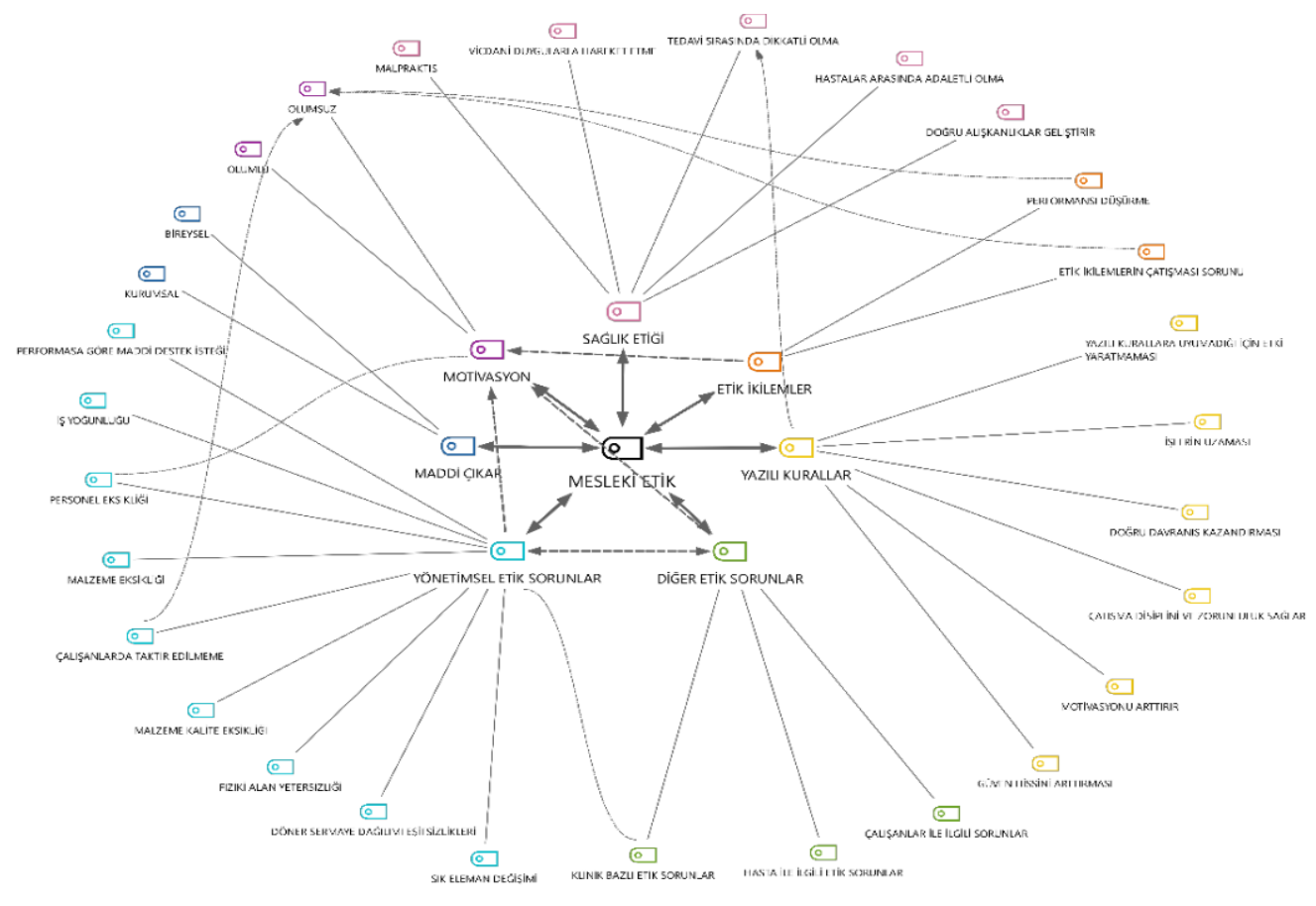

Şekil 1. Kavram Haritası Kodlar ve Alt Kodlar

\subsection{Temalar}

Elde edilen veriler sonucunda etik sorunlar Mesleki Etik kavramı çerçevesinde 7 ana tema olarak tespit edilmiştir. Meslek etiği kavramı çerçevesinde ana kodlar:

* Sağlık Etiği

* Etik İkilemler

* Motivasyon

* Yönetimsel Etik Sorunlar

* Diğer Etik Sorunlar

* Maddi Çıkar Elde Etme

* Yazılı Kurallar olarak belirlenmiştir.

\subsection{Mesleki Etik Teması ile İlgili Kodlar}

Meslek Etiği tüm mesleklerin uyması gereken etik kuralların tümünü ifade etmektedir. Sağlık Etiği mesleki etik davranışların içerisinde en önemlisidir diyebiliriz. Çünkü icra edilen hizmet insan faktörü ile ilgilidir ve sıklıkla yapılan hataların geri dönüşümü yoktur.

Mesleki etik teması sağlık etiği, etik ikilemler, yazılı kurallar, yönetsel etik sorunlar, maddi çıkar elde etme, motivasyon ve diğer etik sorunlar teması ile doğrudan ilişki içerisinde olduğu 
belirtilmektedir. Diğer etik sorunlar, yönetsel etik, etik ikilemler temalarının ise motivasyon temasına vurgu yaptı̆̆ belilenmiștir.

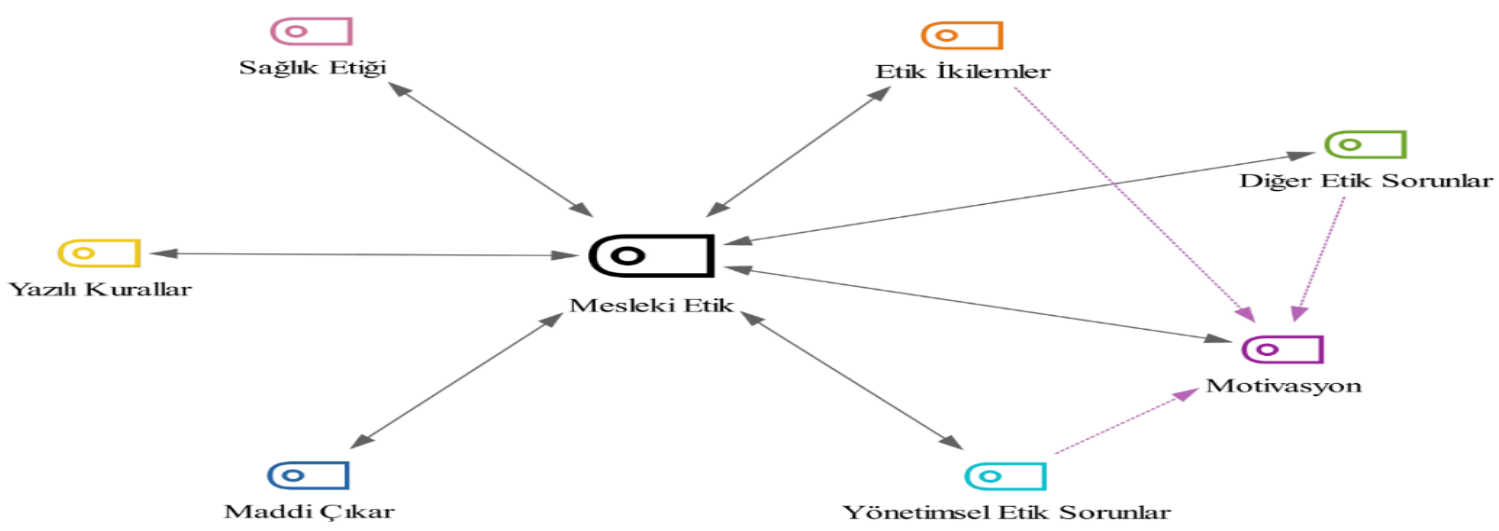

Şekil 2. Mesleki Etik Teması ve Altkodları

"Mesleki etik kurallar nedir? çalışırken sizi ne şekilde etkilemektedir? Açıklarmısınız?" sorusuna sağlık çalışanlarının verdiği bazı ifadeler:

"Sağllkta mesleki etik oldukça önemlidir. Çünkü sağlık hizmetleri çok hassastır. Burada hizmet insan fakrörüdür ve yapılan hatanın geri dönüşümü bazen yoktur. Mesleki etik kuralların uyulmaması malpraktıs dediğimiz sağlıkta ciddi tedavi ve hasta hatalarının artmasina neden olur" (K 20).

"Gece nöbetinde hemşire zamanında ilacını içirip vital bulgularını almazsan hastada ciddi sorunlar olabilir" Mesleki etik kurallar bizi şu şekilde etkiler mesela Hastaya kullanılan malzemelerin kaliteli olmamasi sonucu hastaya yeterince hizmet edilememekte ve bu şartlarda çalışmak motivasyon bozukluğuna sebep olmakta” (K18, K6).

"Hangi meslek grubunda olursa olsun meslek sahiplerinin benimsemesi gereken davranış biçimleridir diyebiliriz. Çalışırken bazen kendimizce bazı alışkanlıklar geliştiririz. İşte bu allşkanlıkların etik ilkelere ve deontolojiye uygun olması önemlidir" (K12).

"Meslek etiğine uymayan davranışlar; örneğin doktorumuz hastadan tetkik istiyor. MR veya başka bir tetkik istiyor. Hastaneye yakın birkaç özel merkez var doktorun hastayı bu merkezlerden birine özellikle yönlendirmesi, kendi aralarında anlaşıp menfaat elde etmeleribana göre çok yanlış (K13).

"Hastalar sıra beklerken sekreterin o sırada başka arkadaşıyla sohbet etmesi veya yoğunluğu aldırmadan çay molası

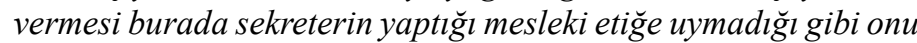
uyarmayan sorumlu hemşirenin hareketi de mesleki etiğe uymaz. Zaman Zaman bu tarz olaylar yaşanıyor".

"Mesela hastalar arasında mümkün olduğunca adaletli davranmaya çalışıyorum. İletişim esnasında eşit zaman ayırmaya çalışıyorum” (K17).

\subsection{Sağlık Etiği Teması ve Alt Kodları}

Tüm meslek gruplarında yapılması gereken ve yapılmaması gereken davranışlar olarak belirlenen mesleki etik kavramının en önemli temalarından biri sağlık etiği ve uyulması gereken etik ilkelerdir. Sağlık etiği alt kodları şekil 3'de verilmiştir. Sağlık etiği temasına ilişkin 5 kod belirlenmiştir.

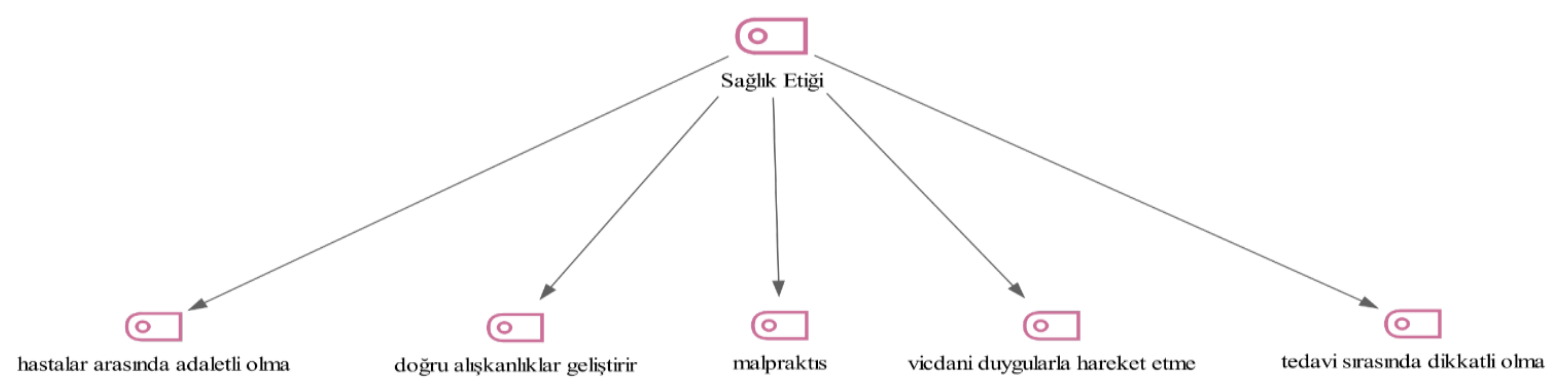

Şekil 3. Să̆lık Etiği Teması ve Alt Kodları 
Mesleki etik kurallar ve sağlık etiği çalışırken sizi ne şekilde etkilemekte? Açıklarmısınız? Sorusuna karşılık sağlık etiği temasına oluşturan ifadeler aşağıda yer almaktadır.

“Tüm mesleklerde olduğu gibi mesleki özellikle să̆lık etiği çok önemli bazen motivasyonu artırır bazen tam tersi olur. Özellikle vicdani bir yanı da vardır (K5). Ama işte çalışma sahasında hayaller ve gerçekler farkll.

Să̆lık etiği topluma karşı işte hastalarımıza karşı olan sorumluluğumuzu ifade etmektedir. Hastaya yaptığımız güzel bir davranış onu mutlu eder ve karşılı̆̆ında iyi hissederiz bir duası bizim motivasyonumuzu artırir” (K7).

"İste hastalar sıra beklerken sekreterin o sırada başka arkadaşıyla sohbet etmesi veya yoğunluğu aldırmadan çay molası vermesi (K22) burada sekreterin yaptı̆̆ mesleki etiğe uymadı̆̆ gibi onu uyarmayan sorumlu hemşirenin hareketi de mesleki etiğe uymaz. Zaman Zaman bu tarz olaylar yaşanmaktadır.”

"Sağllkta mesleki etik oldukça önemlidir. Çünkü sağlık hizmetleri çok hassastır. Burada hizmet insan fakrörüdür ve yapılan hatanın geri dönüşümü bazen yoktur.

Etik kuralların uyulmaması malpraktıs dediğimiz sağlıkta ciddi tedavi ve hasta hatalarının artmasına neden olur (K20).

Gece nöbetinde hemşire zamanında ilacını içirip vital bulgularını almazsan hastada ciddi sorunlar olabilir”

"Să̆llk etiği diğer meslek gruplarına göre daha hassastır. $O$

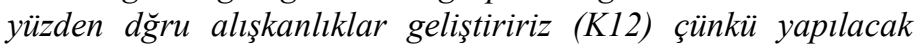
hatalar insan canına mal olacaktır. Hastaya kendi anamız babamızmıs gibi vicdanlı davranırız. (K5) En basiti kan alırken damar yolu açarken hassas olmalıyız sonuçta karşımızdaki hasta ya da çocuk... dikkatli olma ve yetenekli olmaya mecburuz" (K16).

"Să̆lık etiği bence tüm hastalar arasında adaletli olmadır (K17) vicdandır (K5), dikkatli olmadır” (K16).

"Mesela hastalar arasında mümkün olduğunca adaletli davranmaya çalışıyorum. İletişim esnasında eşit zaman ayırmaya çalışıyorum” (K17).

"Yani özel odadaki hasta ile kurduğum iletişim şekli ve zamanı diğer odadaki hastalarla da aynı şekilde olmasını dikkat etmekteyim” (K16, K17).

"Hastalar ve hasta yakınlarına eşit mesafede yaklaşırım. Mesela bir hasta ile olumlu ilişkiler kurarken, sözel iletişim kuararken diğer hasta içinde aynı şekilde iletişim kurmaya çalışırım. İletişim kurmak için geçirdiğim zamanı diğeri içinde aynı şekilde uygularım, bana göre adaletli olmak herkese eşit yaklaşmak çok önemli” (K17).

\subsection{Etik İkilemler Teması ile İlgili Kodlar}

Sağlık çalışanlarının ifadelerinde en fazla yer verdikleri tema etik ikilemler temasıdır. Etik ikilemler sağlık alanında sık sık karşılaşılan durumlar olarak ifade edilmektedir. Etik ikilem ve alt kodlar şekil 4'de yer verilmiştir.

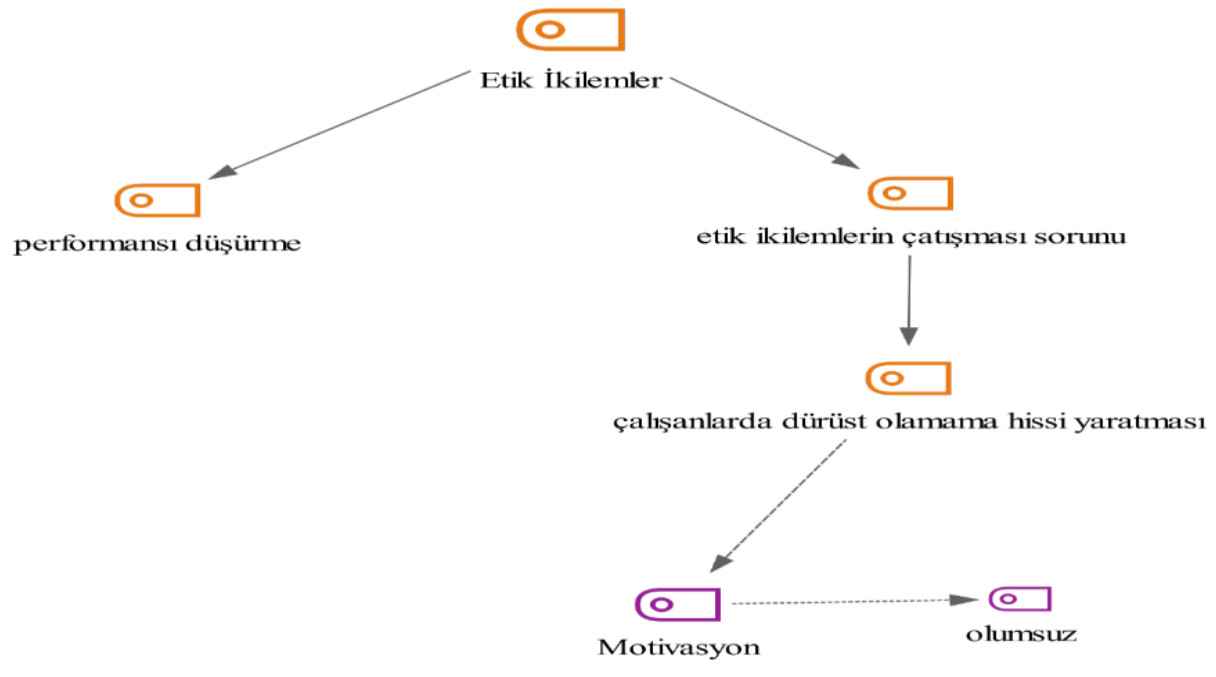

Şekil 4. Etik İkilemler Teması ve Alt kodları

Etik ikilemler sağlık sektöründe görev yapan çalışanların sık karşılaştıkları durumlardan bir tanesidir. Özellikle onkoloji ve palyatif bakımda çalışan hemşireler ya da teknikerlerin hastalıkları ve prognozları nedeniyle net bilgi vermemeleri hastanın hastalığı ile ilgili bilgi alma hakkı ile ters düşmektedir. $\mathrm{Bu}$ gibi durumlar karşılaşan sağlık çalışanlarının duygu durumlarını da etkilemektedir. Nitekim yapılan çalışmada elde edilen verilere göre etik ikilemlerin çalışanların motivasyon ve performansları üzerinde etkili olduğu ifade edilmiştir.

Sağlık sektöründe ya da çalıştığınız klinikte yaşadığınız etik ikilemler nelerdir? Konu ile ilgili neler söylersiniz? Sorusuna verilen ifadelerden bazılarına aşağıda yer verilmiştir. 
“Ölmek üzere olan hastalara ve yakınlarına tedavi yapmaya devam ediyoruz hasta ve yakınına öleceğini söyleyemiyoruz. Ölecek olan hastaya o kadar çok ilaç ve kan takmak ve bu masrafi yapmak ne kadar doğru...boşuna yapılan işlemler ve ekonomik olarak boşa giden masraf”, (K18).

"Hasta ve yakınlarına bilgi verme aşamsında etik sorun yaşıyoruz. Hastalarımız onkoloji hastası prognozları kötüye gidiyor. Bazen hastanın durumu kötü diyemiyoruz. Hasta bilgi almak istiyor ben kansermiyim diyor hayır önlem için ışın yapıyoruz diyoruz çünkü hastanın çocukları hastalığını söylememizi istemiyor" (K15).

"Bizim ya da ne bileyim benim yaşadığım sorun hastaya hastalı̆̆l ile ilgili bilgi verememek...çünkü hasta ya tedaviye alırken hasta soruyor "bu tedaviyi niye yapıyoz hastalığım kötü mü diye? aslında hastanın kendi hastalı̆̆ ile ilgili doğru bilgi alma hakkı var fakat olmuyor. Hasta yakını bize sıkı sıkı tembih ediyor aman hastalığını söylemeyin diye” (K15).

"Hemşirelik mesleğinde sorumluluk verirler, sorumluluk vardır ancak yetkin yoktur...görev tanımında belirsizlikler yaşarsın...doktor bir görev verir görevin olmadiğ l halde bazen hayır diyemezsin. Hayır dediğinde ise doktor kendine saygısızlı yapıldı̆̆ını sürer ve iletişim veya ilişki bozulur. Hatta kin gütmeye kadar gidilebilir” (K4).

"Bu etik ikilemler veya problemler beni etkiliyor. Sanki dürüst değilmişim gibi geliyor motivasyonuma etkiliyor. Bir de hastayla duygusal bağ oluyor zamanla bu beni takllıyor hatta performansımda etkileniyor. Dürüst değilmişim gibi geliyor (K24).

Hasta ve yakınlarına doğru bilgi veremiyoruz hasta ölecek burada tutmaniza gerek yok diyemiyoruz (K18).

Enbüyük etik ikilem doktorların döner sermayeden faydalanması ama bizim daha çok çalışmamız (K18).

\subsection{Yazılı Kurallar Teması ile İlgili Kodlar}

Elde edilen veriler yazılı kurallar ile ilgili olarak 6 alt kod ile doğrudan, 3 alt kodla dolaylı olarak bağlantılı olduğu tespit edilmiştir. Bu alt kodlara şekil 5'de yer verilmiştir.

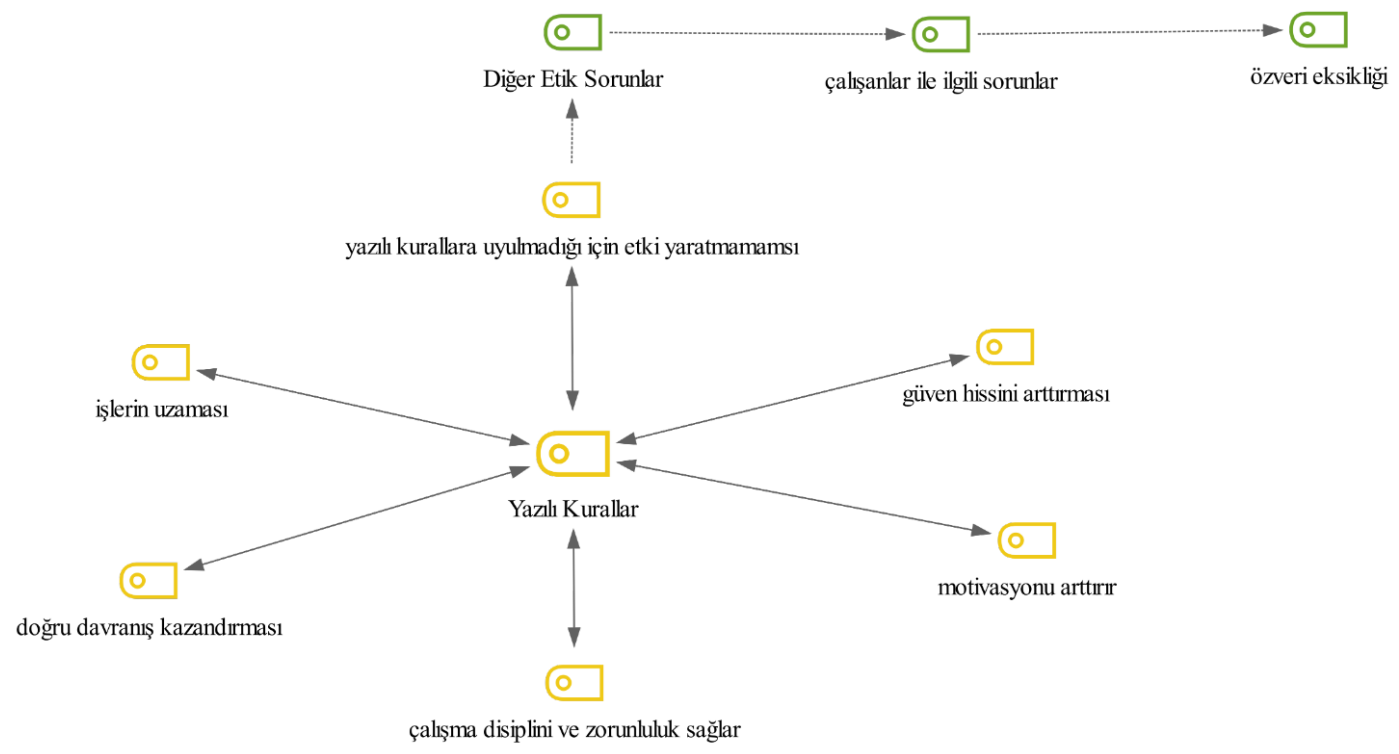

Şekil 5. Yazılı Kurallar ve Alt Kodları

Çalışanların verdiği ifadelere göre yazılı kurallara uyulmaması sonucunda diğer etik sorunlar ve özveri eksikliği kodlarına ulaşıılmaktadır. Ancak yazılı kurallara uyulması olumlu sonuçlar doğurması açısından önemlidir.

Çalışanlara sorulan "yazılı kurallar sizi ne şekilde etkilemektedir?" sorusuna ve verilen cevapların bazıları aşağıda yer almaktadir.

"Yazılı kurallar çallşırken hem kendimi güvende hissetmeme neden olurken diğer açıdan daha dikkatli çalışmam gerektiği yönünde beni motive etmektedir" (K11).

"Yazılı kurallar aslında davranış kazandırdı̆̆g gibi bazı zamanlarda da işlerimizin uzamasına neden oluyor" (K19)
"Nelerin yapılmaması ve yapılması gerektiğini ikaz ettiği için ona göre davranırım” (K19).

"Yazılı kurallar bizi uymamı gereken kuralları daha ciddiye alarak uymamızı sağlar. O anlamda önemli bence. Hastaneye giriş saatimiz 8:15 fakat yazılı kurallar olmasaydı herkes daha esnek gelirdi. Kart basmak bu yazılı kuralların uyulması konusunda konulmuş bir kurallardır ve zamanında gitmeyen kişiler uyarılar ya da savunması alınır. Yazılı kurallar bana göre yazısız kurallardan daha etkili olduğunu düşünüyorum” (K19).

"Kurallara uyulmasını sağlıyor” (K19)

"Türkiye şartlarında yazılı kurallara uyulmamaktadır Ancak işi kaybetme korkusu açısından uyulmalı olarak ezberletilmiştir" (K26) 


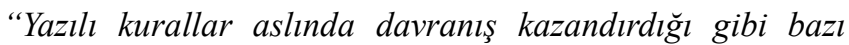
zamanlarda da işlerimizin uzamasına neden oluyor” (K11).

\subsection{Yönetsel Etik Sorunlar}

Sağlık çalışanlarının etik konusunda yaşadıkları diğer sorunlar ise yönetimden kaynaklanan etik sorunlardır. Bu durum diğer etik sorunlarıda bereberinde getirmektedir. Çalışmada sık vurgulanan yönetimsel etik sorunların, sağlık çalışanlarını olumlu ve olumsuz yönde motive ettiği ve hatta performanslarını da etkilediği ifade edilmektedir. Yönetim temelli etik sorunlar ile ilgili alt kod'lar şekil 6 'da yer almaktır.

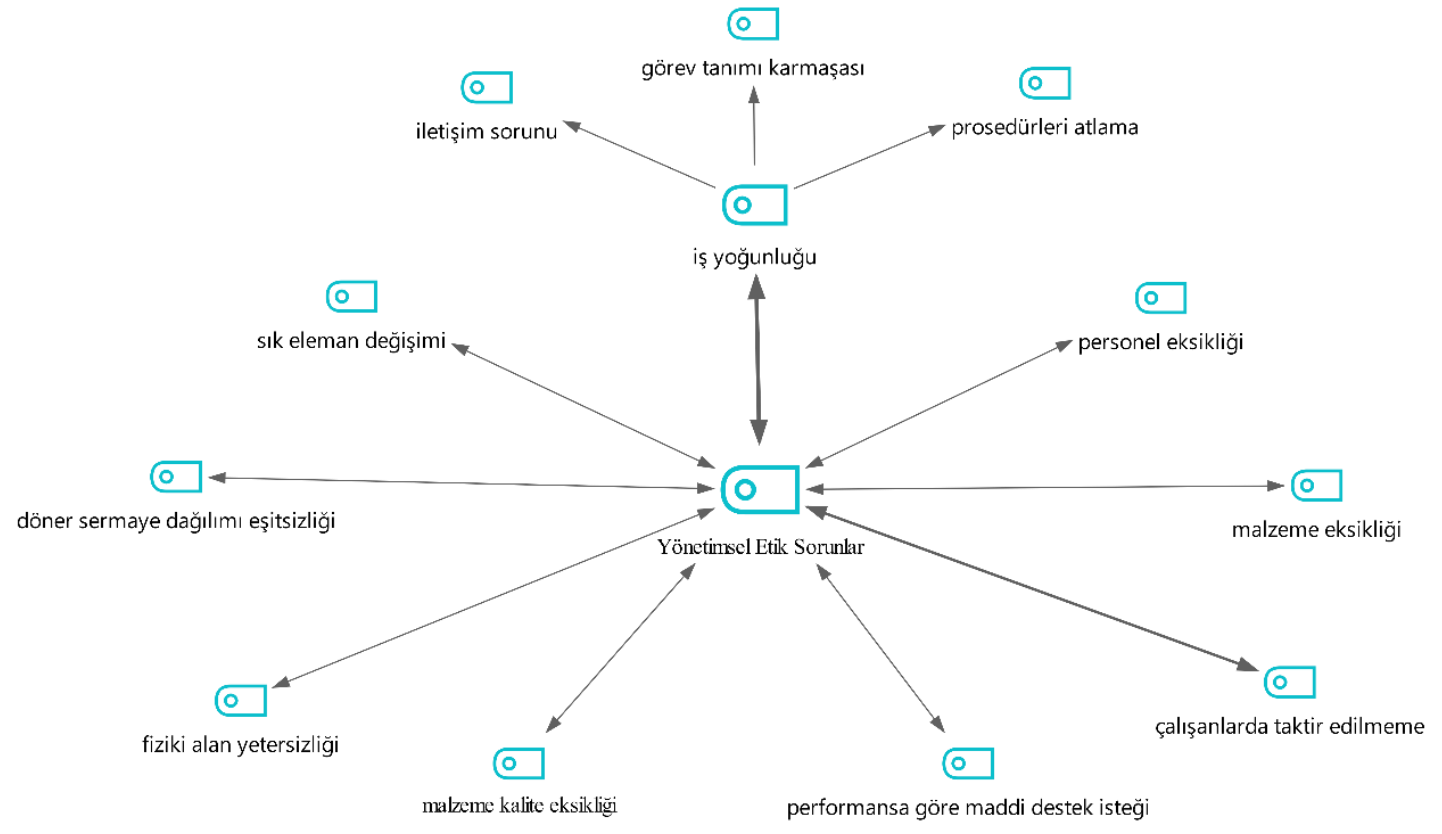

Şekil 6. Yönetim Temelli Etik Sorunlar ve Alt Kodlar

Görüşmelerden elde edilen sonuçlara göre, çalışanların performansı ve motivasyonlarını etkileyen unsurların başında yönetimin uyguladığı tutum ve davranışlar olarak beirtilmiştir. Yönetsel bazdaki bu sorunlar kurum temelli yönetsel sorunlar ve klinik temelli yönetsel sorunlar olarak 2 şekilde ifade edilmiştir. İş yükü, malzeme yetersizliği, eleman yetersizliği, sık eleman değişimi v.b konular kurumsal yönetim temelli etik sorunları ifade etmektedir. Tecrübeli elemanların değer görmemesi, uzmanlık alanına göre çalışanlar arasında eşitsizlik, gereksiz tetkik isteme v.b. sorunlar ise klinik yönetimi bazında ortaya çıkan etik sorunlar olarak belirlenmiştir.

Sağlık çalışanlarına "hastane ve çalıştığınız klinikte hangi konularda etik sorunlar yaşıyorsunuz? Sorusu ve verilen ifadeler aşağıda yer almaktadır.

“Örneğin doktorumuz hastadan tetkik istiyorMR istiyor... hastaneye yakın birkaç özel merkez var doktorun hastayı bu merkezlerden birine özellikle yönlendirmesi...kendi aralarında anlaşıp menfaat elde etmeleri diyebiliriz (K13).

“Valla birçok konuda yaşıyoruz...görev tanımımızdaki belirsizlikler (K4), her işi yapıyoruz, işleri yetiştirme adına hastayla iletişim gerektiği gibi kuramıyoruz (K2). Hatta bazen onam formu almayı unutup sonradan alyoruz bu bir risk hem hasta hem de bizim için..."

"Ben klinik sorumlusu olarak hemşire arkadaşlarıma hoşgörülü ve anlayışlı bir tutum sergilediğim için çalışanlar tüm e-ISSN: 2148-2683 yukardaki olumsuzklara rağmen birbirlerine bağll ve motive olarak çalışıyor. Enerjimiz ve olumlu tutumuz ile birbirimizi etkiliyor parformansimızı ve motivasyonumuzu artırmaya çalışıyoruz. Halbu ki bize maddi anlamda katkı sağlansa ve eksik eleman değişimi, olmasa performansımız daha da artar (K2), Sik elaman değişimi, döner sermayeden maddi ek ödeme olmamasi ve hastaları çoğunlukla ölmesi"” (K23).

"Hastane yönetimi ya da amirler tarafindan takdir görmeme, iş yükü sonucu iletişim eksikliği ya da bazı prosedürleri atlama, hasta ya da yakınına bilgi verme konusunda etik sorunlar yaşıyoruz. işte bir de biraz önce anlattıklarım var (K2, K7).

"Ancak bizden kaynakl olmayan bir takım yönetimsel sorunlardan dolayl etik kurallar ihlal edilebiliyor. Mesela malzeme eksikliği gibi...örneğin temizlik personeli eksikliği gibi nedenler (K3, K6) hasta yakınları bazen hafta sonları çarşaf bulamadıklarını veya çöplerin zamanında alınmaması gibi nedenlerle şikayetçi olabiliyor".

"Böyle durumlarda bize yansıyon olumsuzluklar motivasyonumuzu kırlyor ...ya da işte etik kurllara uymaya gayret ettiğimiz ve olumlu dönüşler aldığımızda idarenin yönetim bazında bize bir teşekkür etmesi bile bizim performansımızı artırmsina yetiyor diyebilrim (K7).

"Hastaya kullanılan malzemelerin kaliteli olmaması sonucu hastaya yeterince hizmet edilememekte ve bu şartlarda çalışmak motivasyon bozukluğuna sebep olmakta” (K23). 
"Yöneticilerin yeterince çalışanlarına ilgi alaka göstermemesi” (K7).

\subsection{Diğer Etik Sorunlar Teması ile ilgili Kodlar}

Etik sorunlar tüm mesleki alanlarda olduğu gibi sağlık alanında da farklı boyutları ile incelenmiş ve değerlendirilmiştir. Diğer etik sorunlar teması altındaki kodlar; hasta ile ilgili sorunlar (iletişim, hijyen, hastanın ekonomik durumu, hasta ve yakınlarının gereksiz istekleri), çalışanlar ile ilgili sorunlar (özveri eksikliği), klinik bazlı sorunlar (hekim ve hemşire iletişimi, tecrübeli elemanların değersizleşmesi, gereksiz kan takılması ve ilaç uygulamaları) şeklinde belirlenmiştir (Şekil 7 ).

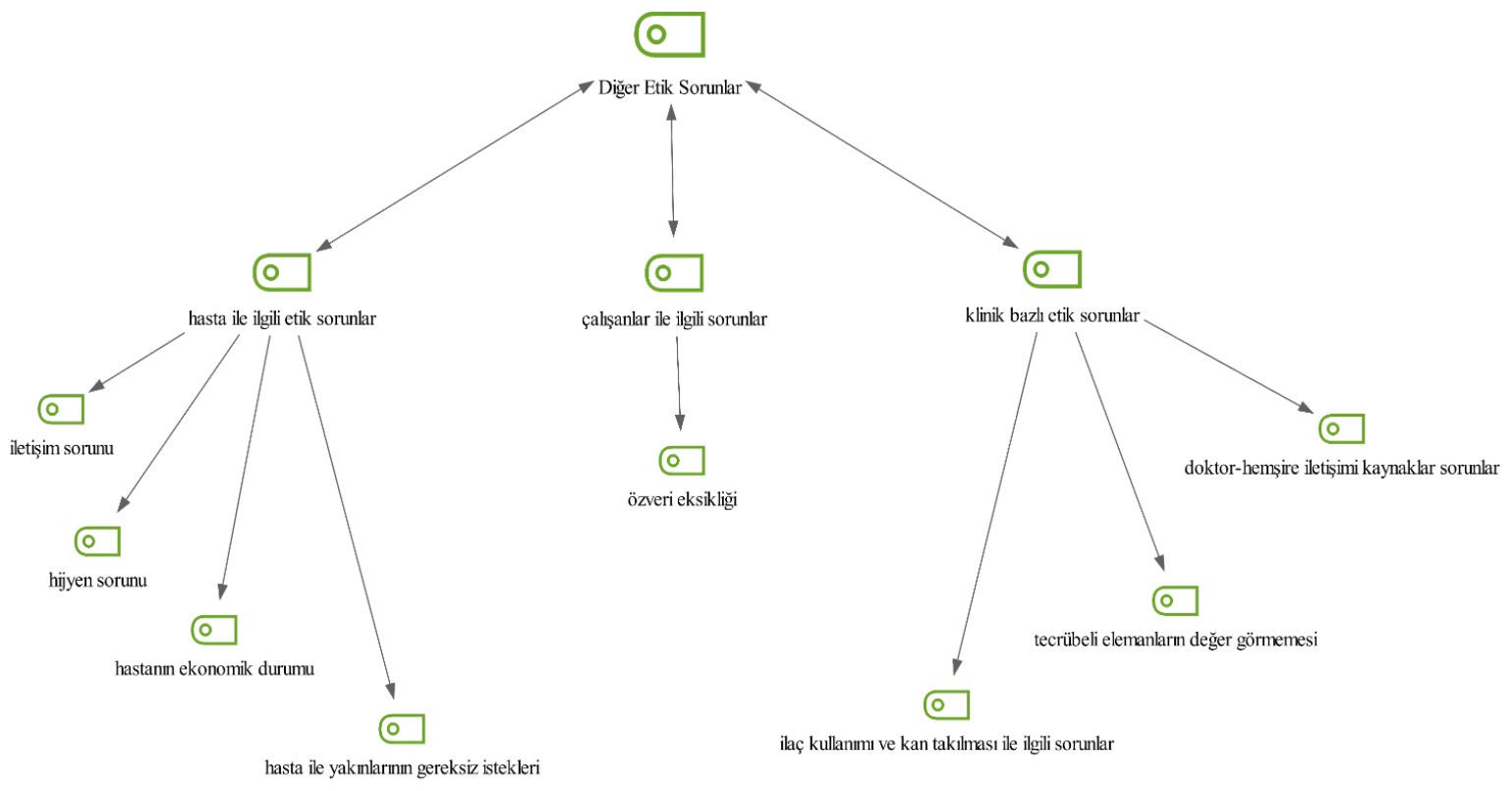

Şekil 7. Diğer Etik Sorunlar ve Alt Boyutları

"Çalışanlara kendi alanınızda çalışırken yaşadğınız başka ne tür etik sorunlar var? Sizi başka neler etkiliyor?" sorusuna verilen cevapların bazılarına aşağıda yer verilmiştir.

"Görev tanımımızdaki belirsizlikler, her işi yapıyoruz, işleri yetiştirme adına hastayla iletişim gerektiği gibi kuramıyoruz. Hatta bazen onam formu almayı unutup sonradan allyoruz bu bir risk hem hasta hem de bizim için” (K2, K4).

"Aslında yaptığımız işin vicdani boyutu diyebilirim (K5). Hasta geliyor bize güzel bir söz bir haber bekliyor, iyileşiyorsun Ali amca dememi istiyor bazen mutlu olsun diye diyorumda halbuki ileri evrede tamamen iyileşme şansı yok hastanın ve biliyor musunuz bazen iyiye gidiyor inşallah iyileşeceksin diyorum ...ne kadar doğru tartışılır yani” (K10).

"Etik sorunlar kesinlikle sadece motivasyonumu değil performansımızı da etkilemektedir. Yönetimsel etik sorunlar, hasta ile olan etik sorunlar, kendi kliniğimiz içinde oluşan etik sorunlar mesleği tam olarak icra etmemizi engeller (K10, K18).

"Bizden kaynaklı olmayan bir takım yönetimsel sorunlardan dolayı etik kurallar ihlal edilebiliyor. Mesela malzeme eksikliği gibi...örneğin temizlik personeli eksikliği gibi nedenler (K3, K6). Hasta yakınları bazen hafta sonları çarşaf bulamadıklarını veya çöplerin zamanında alınmaması gibi nedenlerle şikayetçi olabiliyor. Böyle durumlarda bize yansiyan olumsuzluklar motivasyonumuzu kırıyor...ya da işte etik kurallara uymaya gayret ettiğimiz ve olumlu dönüşler aldığımızda idarenin yönetim bazında bize bir teşekkür etmesi bile bizim performansımızı artırmasina yetiyor diyebilirim” (K23, K7).

“Çalışma şartlarda en köklü sorunu hastalara hasta gözüyle değil müşteri gözüyle bakılmasıdır. Disiplin kuralları uygulanmayı işi bilmeyen insanların yanlış yerlerde olmasıdır" (K1, K18). Işi bilenle bilmeyenin aynı kefeye konulması (K18).

\subsection{Motivasyon Teması ile ilgili kodlar}

Sağlık çalışanları, yapılan görüşmelerde göre farklı etik sorunların motivasyonlarını ve performanslarını etkilediğini ifade etmektedirler. Motivasyon temasına bağlı iki alt kod belirlenmiştir. Motivasyonu olumlu yönde etkileyen durumlar (Hastadan alınan olumlu dönütler, yönetimden gelen olumlu dönütler ve klinik sorumlularının klinik işlerini yönetirken takındıkları pozitif yaklaşımlar) ve motivasyonu olumsuz yönde etkileyen etik durumlar (etik ikilemler, takdir görmeme, yönetimsel sorunlar) olarak tespit edilmiştir (Şekil 8). 


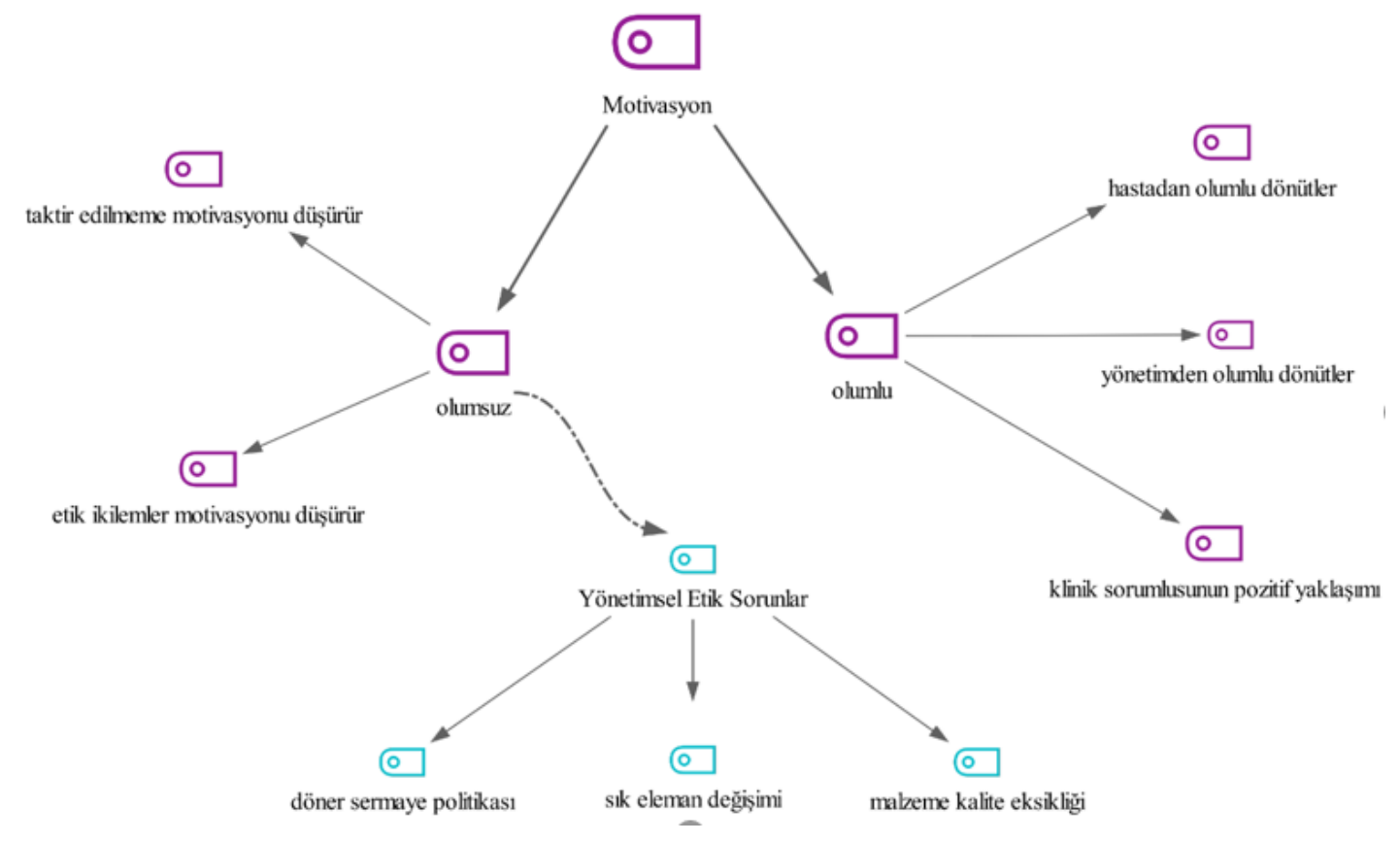

Şekil 8. Motivasyon Temasl ve Alt Kodlarl

"Bize yanslyan olumsuzluklar motivasyonumuzu kırlyor ...ya da işte etik kurallara uymaya gayret ettiğimiz ve olumlu dönüşler aldığımızda idarenin yönetim bazında bize bir teşekkür etmesi bile bizim performansimızı ve motivasyonumuzun artmasina yetiyor diyebilirim (K7).

Böyle yoğun bir yerde çalışlyoruz ve hastalarımı ölüyor (K2), işimiz ölmek üzere olan hastaya bakma ve sonunda hepsi ölüyor bu durum bizim hatta hekimlerin bile motivasyonunu düşürüyor (K15). Sanki yaptığımız hiçbir şey işimize yaramıyor gibi geliyor. Diğer konu döner sermayaden aynı ücreti alıyoruz halbuki biz yoğun bakım gibi çalışıyoruz ve ek bir katkı sağlamıyor maddi katkısı da olmuyor. Bunun yanında sık sık eleman değişiyor (K27, K23).

Bu etik ikilemler veya problemler beni etkiliyor. Sanki dürüst değilmişim gibi geliyor motivasyonuma etkiliyor. Bir de hastayla duygusal bă̆ oluyor zamanla bu beni etkilityor hatta performansımda etkileniyor (K15).

"Hastaya kullanılan malzemelerin kaliteli olmaması sonucu hastaya yeterince hizmet edilememekte ve bu şartlarda çalışmak motivasyon bozukluğuna sebep olmakta” (K23).

\subsection{Maddi Çıkar Teması ile İlgili Kodlar}

Maddi çıkar teması ile ilgili alt kodlara bakıldığında kurumsal çıkar elde etme ve bireysel çıkar elde etme olarak tespit edilmiştir. Kurumsal çıkar sağlama alt kodu ile vurgulanan bu özellik ise şu şekilde ifade edilmiştir. "Devlet hastaneleri kovit nedeni ile hasta kabul etmediği için özellikle özel hastanelerde firsat yaratılarak fiyatları artırma yoluna gidilerek hastalara hasta gözü ile değil müşteri gözü ile bakılmaktadır" şeklinde ifade edilmektedir. Diğer kurumlara yönlendirme alt kodunda ise o kurumla bir şekilde ilişkisinin bulunan kişilerin dolaylı olarak kişisel çıkar elde edildiğinden bahsedilmiştir. Ancak bu durumun geçmiş yıllarda da fazla görüldüğü de vurgulanmıştır (Şekil 9). Size göre sağlık çalışanlarında kurumsal ya da kişisel olarak etik olmayan tutum ve davranışlar nelerdir? sorusuna verilen yanıtlara aşağıda yer verilmiştir.

"Bana göre çıkar elde etme etik değildir. Sahada bunları görüyor muyuz? evet şu an olmasa bile çok gördük. 10 yılın üzerindeki çalışma hayatımda birçok olaya tanık olduk (K23).

"Örneğin doktorumuz hastadan tetkik istiyor...MR istiyor...hastaneye yakın birkaç özel merkez var doktorun hastayı bu merkezlerden birine özellikle yönlendirmesi ... kendi aralarında anlaşıp menfaat elde etmeleridiyebiliriz “(K13).

Ylllar öncesine baktı̆̆ımda bu tarz durumlar daha fazla olmaktayd y ya da ben öyle düşünüyorum. Hediye almalar ya da bir şekilde istemeler, bir şey karşılığında dışardan birilerinin işlerini yapmalar gibi durumlar yani..rüşvet de diyebiliriz (K13).

"Özel hastanelerde para odaklı değil hasta odaklı olmalı hizmet verilmeli" (K1).

"Düşük maaş uğruna bilinçsiz eleman çalıştırma. Ya da az maliyetle çok kazanç uğraşları, hastayı müşteri görmek” (K13, K25). 


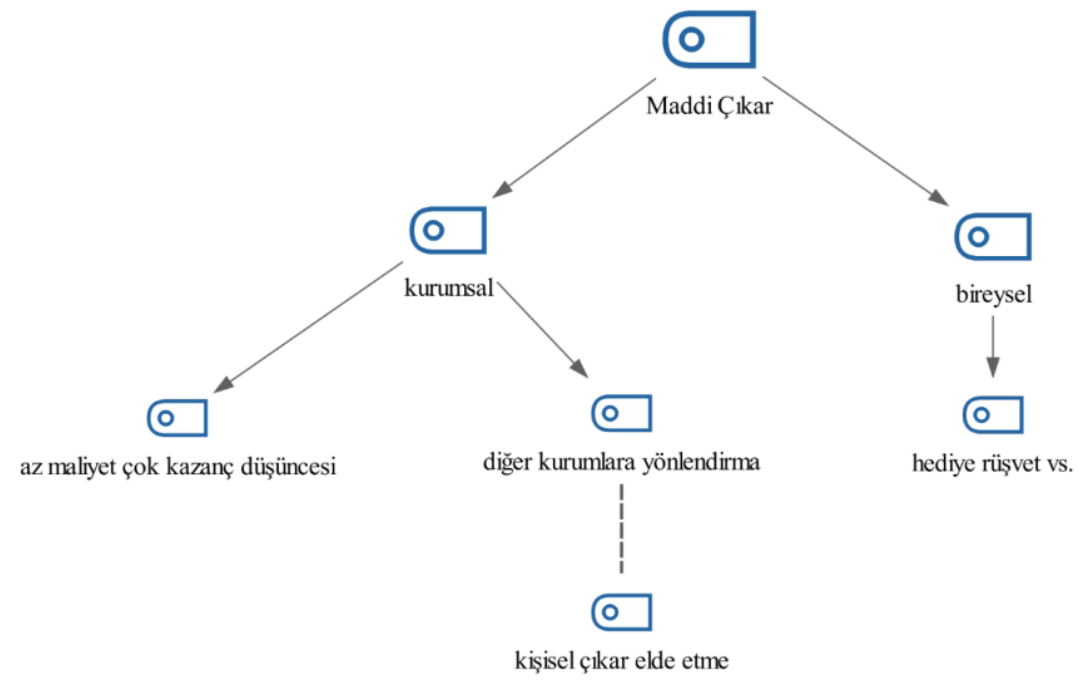

Şekil 9. Maddi Çıkar Sağlama ve Alt Kodlar

\section{Tartışma ve Sonuç}

Çalışma içerisinde yer alan etik ile ilgili değerlendirmelerde, özellikle sağlık temelinde ele alındığında, kavramın hayati değerler açısından ele alınmaya çalışıldığı görülmektedir. Buna göre sağlık sektörü, kuralları bazında etik hareket etme zorunluluğuna sahip olmakla birlikte sürecin içerisinde en belirleyici unsur, etik kavramına çalışanların bakış açısı olmaktadır.

Araştırma içerisinde, literatürdeki farklı çalışmaların sonuçları değerlendirildiğinde, özellikle sektör çalışanlarının etik algısının yeterince yüksek olduğu görülmektedir. $\mathrm{Bu}$ araştırmalarda dikkati çeken iki unsur söz konusudur. Bunlardan ilki, sağlık sektörü çalışanlarının, sektör içerisinde etik olarak görmedikleri bir davranışı, doğrudan doğruya üstlerine ya da yetkili mercilere bildiriyor olmalarıdır. Buna istinaden sektör çalışanlarının etik algısının yüksek olduğunu düşünmek mümkündür. Çünkü kuralları bilen ve bunları uygulama arzusunda olan sağlık sektörü çalışanları için fark ettikleri etik konulara dair eksiklikleri hızlı bir şekilde üstlerine iletmeleri, konuya dair, insan sağlığıyla ilintili hassasiyetlerinin son derece yüksek olduğunu göstermektedir.

Öte yandan, literatürdeki farklı çalışmaların sonuçları değerlendirildiğinde, dikkati çeken ikinci bir unsur ise sektör çalışanlarının, çevrelerinde, sektörlerine dair görmüş oldukları etik dışı olaylara ve bunların devamlılı̆ğna karșı iş performanslarının durumudur. Buna göre sektör çalışanları, kendi çevrelerinde herhangi bir etik dışı davranışla karşılaşmış oldukları süre zarfında, bunun çözüme kavuşmadığını ya da kavuşma ihtimalinin olmadığını, kötü şartların halen devam ettiğini gördükleri an itibari ile bu etik dışı durumdan etkilenerek düşük bir performans sergilemektedirler. $\mathrm{Bu}$ durum, sağlık sektörü çalışanların etik konulara ne denli önem verdiklerinin ve etik dışı bir çalışma ortamında ne denli verimsiz olarak çalıștıklarının da bir göstergesidir. Hastane Ortamında Hemşirelerin Etik Yaklaşımı ve Etik İkilemler başlıklı benzer çalışmadaki vaka araştırması yapılmış ve bazı yönleri ile benzer sonuçlar çıkmıştır. Benzer sonuçlar malzemelerin bulundurulması ile ilgili etik sorunlar, hastaların yararına verilecek kararlarda etik sorunlar sonucu çıkmıştır. Bizim araştırmamızda ise bununla ilgili hastaya karşı net cevaplar verememenin çalışanları dürüst davranmama hissi ile motivasyonlarının düştüğü ş̧eklinde ifade edilmiş ve motivasyon temasında vurgulanmıştır. Aynı durum çalışanların yaşadığı etik ikilemler temasında da yer almıştır. N. Utlunun çalışmasında cerrahi hemşirelerinin yaşadığı etik sorunlarda hemşirelerin kürtajı doğru bulmadığı halde işlemde görev almaya iliş̧in etik uygulama sorunlar yaşadıkları belirlenmiştir. Araştırmamızda palyatif bakım hemşirelerinin ölmek üzere olan hastalara serum, kan v.b uygulamaların yapılmasını doğru bulmadıklarını belirtmişlerdir. Ancak görevleri gereği söylenen ya da planlanan tedavi şemasını uygulamak zorunda olduklarını belirtmişlerdir. $\mathrm{Bu}$ ifadeler yönetim temelli etik sorunlar temasında ve motivasyon temasında irdelenmiştir. .

Carlise Rigon Dalla Noraa ve arkadaşlarının 2013 yılında yaptığı BDTD, CINAHL, LILACS, MEDLINE, Biblioteca Cochrane, PubMed, RCAAP ve SciELO veri tabanlarından portekizce, ingilizce, ve ispanyolca tezler ve makaleler dahil edilerek yapılan literatür çalışmasında etik konusu ile ilgili en fazla çalışma yapılan alanın sağlık etiği ve hemşirelerin karşılaştıkları etik sorunlar üzerine yapıldığı belirlenmiştir. Bu yönüyle sağlık alanında ortaya çıkan sorunlar, hastane yönetimi anlamında da önem taşımaktadır. Diğer çalışmalarda genel olarak klinik çalışmalar konusunda araştırma yapılmıştır. Çalışmamızda bu sorunların büyük bölümünün yönetim temeli üzerine dayandığı vurgulanmıştır. $\mathrm{Bu}$ nedenle çalışmada sağlık profesyonellerinin yaşadıkları yönetsel etik sorunların motivasyonlarını olumsuz şekilde etkilediği gibi yönetim tarafından değer görmenin ise performans ve motivasyonlarını arttırdığ belirlenmiş̧ir. Çalışanlar; Yönetsel etik kaygılar denildiğinde kurumsal yönetim ve klinik yönetimi olmak üzeri 2 tür yönetim vurgusu yapmıştır.

Çalışmamızın sınırlılıklarını farklı kliniklerde çalışan hemşire ve sağlık teknikerleri oluşturmaktadır. Hekimler ve aynı klinikte çalışan kişiler araştırma kapsamı dışındadır. Söz konusu sağlık çalışanları basit rastgele örneklem seçim tekniği ile tercih edilmiştir. Basit rastgele örneklem seçimi, evren içerisinden seçilebilecek olan her bireyin seçilme şansının eşit olduğu ve 
böylelikle evreni yansıtabilme ihtimalinin arttığı bir yöntemdir (Aziz, 2011; Büyüköztürk vd.,2016). Şubat - Nisan 2021 tarihleri arasında İstanbul İli içerisinde kamu ve özel hastanelerde görev yapan sağlık çalışanlarını kapsamaktadır. Araştırmanın örneklemini farklı kliniklerde (onkoloji, kemoterapi, cerrahi, paltyatif bakım) çalışan hemşireler ve teknikerler (radyoterapi, nükleer tıp, anestezi) oluşturmaktadır

Elde edilen verilerden yapılan analiz sonucunda 7 ana tema ve alt kodları tespit edilmiştir. Mesleki Etik temasının çerçevesinde; sağlık etiği, etik ikilemler, motivasyon, yönetimsel etik, diğer etik sorunlar, maddi çıkar elde etme, yazılı kurallar temaları belirlenmiştir. Mesleki etik temasında dikkat çeken motivasyon temasının yönetsel etik, etik ikilemler ve diğer etik sorunlar kodları ile ilişkili olduğu yönündedir. Bu 3 alt kod çalışanların motivasyonlarını ve performanslarını olumlu yönde ve olumsuz yönde etkilemektedir. Etik ikilemler çalışanlar üzerinde hastaya karşı dürüst değiliz hissi yaratarak çalışanların motivasyonlarını düşürürken kullanılan malzemelerin kalitesizliği ve malzeme eksikliği, çalışanlara karşı duyarsız davranma gibi yönetim bazlı etik sorunlar da motivasyonu olumsuz etkilemektedir. Diğer etik sorun alt temasının klinik bazlı sorunlar bölümünde yer alan tecrübeli elemanların değer görmemesi de motivasyonu düşürdüğü yönündedir. Yazılı kurallar temasında dikkat çekici nokta genel anlamda uyulması yönünde olumlu sonuçlar verdiği ve çalışanları güvende hissettirdiği yönünde olduğu tespit edilmiştir. En önemlisi ise çalışanların çalışma sırasında doğru alışkanlıklar geliştirmeleri yönünde etkili olduğunu ifade etmeleridir. Yönetimsel etik teması ise etik sorunların çalışanlar tarafindan en çok vurgulandığ 1 tema olmasıdır. Yönetimsel etik sorunlar iş yoğunluğu, personel eksikliği, malzeme eksikliği, malzeme kalite eksikliği, takdir görmeme, fiziki alan eksikliği, döner sermaye eşitsizliği, sık eleman değişimi gibi alt kodlar tespit edilmiştir.

Tüm meslek grubunda olduğu gibi sağlık hizmetleri alanında da etik kurallar ve bu kurallara uygun davranış geliştirme, hem hasta açısından hem de deontoloji anlamında önemlidir ve bu hizmetleri etkilemektedir. Yönetim hizmetlerinin çalışanlara yönelik motivasyonlarını yükseltmek adına klinik bazında, malzeme ve malzemelerin kalitesi bazında, maddi teşvik bazında ve küçükte olsa takdir edildiklerini gösteren davranışlar bazında daha etkili olmaları çalışanları motive etme ve performanslarını yükseltme anlamında önemli olacağı düşünülmektedir. $\mathrm{Bu}$ bağlamda çalışanların takdir edildiklerini gösteren, teşekkür yazıları ya da sözel geri bildirimler yapılarak motivasyonlarını arttırılması önerilmektedir. Hastane yönetim ekibinin malzemelerin kalitesi ve eksik malzemelerin, zamanında tedarik edilmesi noktasında daha duyarlı olması önerilmektedir çünkü bu durum hasta ve yakınları ile sürekli iletişim halinde olan çalışanların streslerinin azaltılması bakımından önemlidir. Klinik yönetimin, çalışanlarına mesai saatleri konusunda eşit davranmas1, mümkün olduğunca etik ikilem konusunda da çalışanlarla ortak çözüm noktaları üzerinde fikir alışverişinde bulunması önerilmektedir.

\section{Teşekkür}

Çalışmada destek olan kamu, vakıf ve özel hastanede çalışan hemşire ve teknikerlere teşekkür ederim.

\section{Kaynakça}

Avc1, M., \& Teyyare, E. (2012). Sağlık sektöründe yolsuzluk: Teorik bir değerlendirme. Ekonomik ve Sosyal Araştırmalar Dergisi, Cilt:8, Y11:8, 2, 8:199-221

Aziz, A. (2011). Sosyal Bilimlerde Araştırma Yöntemleri ve Teknikleri. Nobel Yayınları, Ankara

Büyüköztürk, Ş., Kılıç, E., Akgün, Ö., Karadeniz, Ş. \& Demirel, F. (2016). Bilimsel Araştırma Yöntemleri. Pegem Akademi, Ankara.

Creswell, John W. Nitel Araştırma ve Araştırma Tasarımı: Beş Yaklaşımdan Seçim. SAGE, 2013. 448 sayfa

Doğan, S., \& Karataş, A. (2011). Örgütsel etiğin çalişan memnuniyetine etkisi üzerine bir araştirma. Erciyes Üniversitesi İktisadi ve İdari Bilimler Fakültesi Dergisi, (37), $1-40$.

Durmaz, T., \& Erdem, R. (2017). Hastanelerde Arz Kaynaklı Gereksiz Sağlık Hizmeti Kullanımının Hasta Algısı Üzerinden Değerlendirilmesi. Süleyman Demirel Üniversitesi Sosyal Bilimler Enstitüsü Dergisi Y1l: 2017/4,29:579-604.

Dündar, T. (2010). Sağlık çalışanlarının yıldırmaya maruz kalmalarında hastane etik iklimi ile sosyodemografik özelliklerinin rolü: Bolu ili hastanelerinde bir araştırma. Hacettepe Üniversitesi Sağllk bilimleri Enstitüsü Yüksek Lisans Tezi, Ankara.

Eğri, T. (2008). Marksist Ahlak ve Toplum Teorisi. İş Ahlakı Dergisi, 1(1), 163-167.

Gül, H. (2006). Etik Dışı Davranışlar Ve Ussallaştırılması: Devlet Hastanelerinde Bir Uygulama. Selçuk Üniversitesi Karaman I.I.B.F. Dergisi, 10(9), 65-79.

Gülay Yıldırım, Selim Kadığlu. (2007). Etik ve Tıp Etiği Temel Kavramları Cumhuriyet Üniversitesi, Tip Fakültesi Dergisi, 29 (2): 7-12.

Günaydın, H. (2012). Sağlık Sektörüne Bakış. Ankara: Nobel Kitabevi.

Gürkan, C. (2013). Adam Smith'in Police Kavramı. FLSF (Felsefe ve Sosyal Bilimler Dergisi), (16), 149-174.

Kuçuradi, İ. (1997) "Etiğe Yaklaşımlar, Etikte Yaklaşımlar ve Bir 'Evrensel Etik Düşüncesi' ", Uluslararası Felsefe Kuruluşları Federasyonu ile Türkiye Felsefe Kurumu'nun Göreme'de Düzenlediği Seminer.

Kırılmaz, H. ve Kırılmaz, S. K. (2014). Sağlık Hizmetlerinde Etik İkilemlerde Ampirik Etik Çalışmalarının Yararları, İnsan \& İnsan, (1), 35-44.

Kördeve, M. K. (2017). Özel Sektör Sağlık Çalışanlarında Etik Tutum ile Whistleblowıng Arasındaki İlişki. Sağlık Yönetimi Dergisi, 1(2), 51-61.

Kutlay, O., \& Yılmazlar, A. (2001). Anestezi ve yoğun bakımda etik, klinik etik. Ed. Erdemir Demirhan, Nobel Tip Kitabevi, $s, 532-541$.

Levent, A. (2013). İktisat ve Etik: Amartya Sen Mirası. İş Ahlakı Dergisi, 6(2), 109-133.

Livvarçin, Ö., \& Kurt, D. (2012). Yönetim biliminde 49 insan 49 teori. Beta Yayıncilı Boston.

Lois Snyder (2005) American College of Physiçians Ethics Manual, for the American College of Physicians Ethics, Professionalism, and Human Rights Committee.

MEGEP (2011). Sağlık Meslekleri Etiği. Ankara: MEB Yayını.

MEGEP (2015). Sağlık Hizmetleri Meslek Etiği ve İlkeleri. Ankara: MEB Yayını. 
Neuman, W. L. (2007) Sosyal Araştırma Yöntemlerinin Temelleri: Nitel ve Nicel Yaklaşımlar. 2. Baskı, Allyn ve Bacon,

Öztürk, A. (2015). Kapitalizmde Sömürü ve Adalet Tartışmaları. Amme İdaresi Dergisi, 48(2), 23-36.

Palac1, H., Günay, O., \& Yarar, O. (2018). Türkiye'deki radyasyon güvenliği ve koruma eğitiminin değerlendirilmesi. Avrupa Bilim ve Teknoloji Dergisi, (14), 249-254.

Roberts, M. J. (2010). Sağlık Reformunun Doğru Yapılması Performans ve Hakkaniyetin Geliştirilmesi İçin Bir Kılavuz (Çev. Sağlık Bakanlığı). Ankara: Onur Matbaacılık.

Şahinoğlu A. \& Bebek G. (2018). "Araştırma Görevlilerinin Bilimsel Araştırma Etiğgine İlişskin Algıları" Nitel Bir Çalışma Adnan Menderes Üniversitesi Ĕgitim Fakültesi Eğitim Bilimleri Dergisi. 9(1), 47-58

Şahin, B. ve Dündar, T. (2011). Sağlık Sektöründe Etik İklim Ve Yıldırma (Mobbing) Davranışları Arasındaki İlişkinin İncelenmesi. Ankara Üniversitesi SBF Dergisi, 66(1), 129159.

Şen, H. T. (2013). Kamu Hastanelerinde Görev Yapan Başhekim ve Başhemşirelerin Duygusal Zekâ Düzeyleri ile Etik Muhakeme Yetenekleri ve Etkileyen Faktörler. Hemşirelikte Eğitim Ve Araştırma Dergisi, 10(3), 18-26.

Tepecik ve Yazıcı (2012). Sağlık Sektöründeki Etik Problemlerinin Nedenleri. "International Conference On Eurasian Economies 2012" içinde, 382-388.

Türk Kardiyoloji Derneği (2009). Alternatif ve Tamamlayıcı Tıp ile İlişkilerde Etik. Türk Kardiyoloji Derneği Araştırma Dergisi, (37), 33-35.

Uğur, A. A. (2011). Hastaneler ve Sağlık Çalışanlarının Uygulamalarında Etik. Sağlık Hizmetlerinde Etik Anlayışı. Hastane Dergisi, (72), 48-56.

Utlu N. (2016) Hastane Ortaminda Hemsirelerin Etik Yaklasımı ve Etik İkilemler. İstanbul Aydin Üniversitesi Dergisi, 8(29):17-35

World Medical Association. (2015). World Medical Association Declaration of Helsinki: ethical principles for medical research involving human subjects. Ferney-Voltaire, France: WMA, 2008.

Yıldırım, T. (2012). Marksizm'in 100 Kavramı Şırnak Üniversitesi İlahiyat Fakültesi Dergisi, 1(8), 276-279.

Köseoğlu Z. (2011). İonna Kuçuradi'nin Etik Görüşü açısından Kant'ta "İyi İsteme" Problemi Yüksek Lisans Tezi. 